Toplum Bilimleri Dergisi - Journal of Social Sciences

ISSN: 1306-7877 e-ISSN: 2147-5644

Aralık / December 2019, 27 : 455-484

Cumhuriyet Döneminde Amerikan Emperyalizminin Türkiye'ye Girişi: Thornburg Raporu

Entrance of American Imperialism into Turkey During the Period of the Rebublic: Thornburg Report

\title{
Yaşar SEMIZ
}

Prof. Dr.,Selçuk Üniversitesi, Sosyal Bilimler Meslek Yüksekokulu,

Prof. Dr.,Selçuk Üniversity, Vocational School of Social Sciences

Konya, Turkey

ysemiz08@gmail.com

https://orcid.org/0000-0002-9204-8014

\section{Güngör TOPLU}

Öğr. Gör., Selçuk Üniversitesi, Atatürk İlkeleri ve İnkılâp Tarihi Bölümü, Lecturer Selçuk Üniversity

Department of Atatürk's Principles and History of Turkish Revolution Konya, Turkey

gtoplu@selcuk.edu.tr

https://orcid.org/0000-0002-0511-3528

Makale Bilgisi / Article Information

http://dx.doi.org/10.29228/tbd.2007.7395

Makale Türü / Article Types: Araştırma Makalesi / Research Article

Geliş Tarihi / Received: 30 Mayıs / May 2019

Kabul Tarihi / Accepted: 29 Ağustos / August 2019

Yayın Tarihi / Published: 31 Aralık / December 2019

Yayın Sezonu / Pub Date Season: Aralık / December 2019

Cilt / Volume: 27

Sayfa / Pages: 455-484

Copyright @ Publishedby Toplum Bilimleri Dergisi - Journal of SocialSciences.

Allrightsreserved. wwww.toplumbilimleri.com 


\section{Cumhuriyet Döneminde Amerikan Emperyalizminin Türkiye’ye Girişi:}

\section{Thornburg Raporu}

Öz: İkinci Dünya Savaşı'nın sonunda Türkiye yeni bir kalkınma hamlesi başlatabilmek için yurt dışından hem maddi destek hem de teknoloji alma ihtiyacını duydu. 1947 yılında Türk Hükümeti, makine ve teçhizat için yardım alabilmek ümidiyle Amerika'dan Marshall Planı'nın kapsamına alınması ve bu plan çerçevesinde 615 milyon dolar yardım yapılması talebinde bulundu. Uluslararası ilişkilerde kısa sayılabilecek bir süre içinde Amerikan Hükümeti tarafından Türkiye'nin talebi uygun bulundu. Türkiye Temmuz1948'de Marshall Planı kapsamına alındı ve iki ülke arasında İktisadi İşbirliği Anlaşması imzalandı. İşte Thornburg Raporu, bu anlaşma çerçevesinde gündeme gelmişti. Anlaşmayı izleyen aylarda yardım programını yürütecek bir Amerikan Heyeti Türkiye'ye gelerek Ankara'ya yerleşti. Raporu hazırlayacak heyetin başındaki isim olan Thornburg, 1947 yılında Bahreyn'deki petrol arama çalışmalarında bulunmuştu. Thornburg, o dönemde Türkiye'yi de ziyaret etmiş ve ülkenin genel durumu hakkında incelemelerde bulunarak bilgi sahibi olmuştu.

Thornburg Raporu olarak anılan çalışma American Standart Oil Şirketi'nden Max Weston Thornburg'un, Graham Spry ve George Soule ile birlikte 1949- 1950 yillarında yaptığı incelemeler sonucunda 1949 yılında "Türkiye Nasıl Yükselir?" ve 1950 yılında yazdığı “Türkiye'nin Ekonomik Durumunun Tenkidi” adlı iki çalışmayı içermektedir.

Raporlarda Türkiye'de nitelikli uzman ve danışmanların eksikliğine vurgu yapıldıktan sonra, iyi yetişmiş yöneticiler ve uzman personelin sağlanması için liyakat ilkesine önem verilmesi ve ücret sisteminin de bunu geliştirecek düzeyde olması gerektiği üzerinde durulmuştur. Ülkede tarımın geri kalmışlı̆̆ı ve yanlış kullanılan 20. yüzyıl endüstriyel üretim tekniklerine ilişkin gözlemlerinin ardından daha temel ihtiyaçların karşılanmasına yönelik öneriler sıralanmıştır. Bu öneriler arasında kırsal kesimde yaşayan halkın yol, su, elektrik benzeri ihtiyaçlarının karşılanması için hafif sanayi üretimine, tarımsal büyümeye, özel girişime dayalı ihracat temelli madenciliğe ve tüketim mallarına yönelik yatırımlar yapılması hakkında öneriler dikkat çekmektedir.

Türkiye'nin kalkınmasında önemli bir yere sahip olan Karabük'teki Demir-Çelik tesisleri oldukça sert bir şekilde eleştirilerek bunların olgunlaşmamış ve yararlı olmaktan uzak yatırımlar olduğu belirtilmektedir. Ayrıca Sovyetler Birliği (SSCB) desteği ile yapılan yatırımlar eleştirilmekte ve bu devletin yatırım desteğine karşı çıkılması vurgulanmaktadır.

Önerilen yatırımlar konusunda ise Amerika'nın hem iş tecrübesine ve hem de yardımlarına (sermaye yatırımı, dış borç/kredi, dış yardım) sığınılması tavsiye edilmektedir. 
Anahtar Kelimeler: Türkiye, Amerika, Thornburg Raporu, Emperyalizm, Planlama

Entrance of American Imperialism into Turkey During the Period of the Rebublic:

\section{Thornburg Report}

Abstract: At the end of the World War II, Turkey required receiving both financial and technological support from the international platform toinitiate a new development phase. In 1947, hoping to get assistance for machinery and equipment, theTurkish Government requested USA to include Turkey in the Marshall Plan and asked for a 615 Million USD support under that scope. Turkey's request was found suitable by the USA Government which was a short period of time in international relations standards. Turkey was included in the Marshall Plan in July 1948 and two countries executed an Economic Cooperation Agreement. Hence, Thornburg Report was brought up under this agreement. An American delegation came toTurkey and moved to Ankara to conductits support programs in the following months. Thornburg, thehead of the delegation to prepare the report, was in 1947 in the oil exploration work in Bahrain.

Thornburg, at that time visited Turkey and had information about the overall situation in the country.

This Report involves two studies, titled as "How will Turkey rise?" in 1949 and "Turkey: An Economic Appraisal" in 1950, authored by Max Weston Thornburg from American Standard Oil Company together with Graham Spryand George Souleuponre views between 1949-1950.

The Reports suggestmeeting the basic needs more after providing observations regarding the lack of qualified experts and consultants in Turkey, agricultural under developmentand falselyused manufacturing techniques. Following the observations of the backwardness of agriculture in the country and the misusedindustrial production techniques of the 20th century, suggestions were made tomeet the more basic needs.

The Reports further suggest that there should be investments towards light industrial production, agricultural development, export-basedmining based on private enter prise and consumer goods to meet the road, water, electricity and similar needs of peopleliving in the rural area.

Having a significant place in the development of Turkey, Karabük Iron and Steel facilities were criticized as being far from being beneficial. Furthermore, the Reports criticized the investments, done with the help of the USSR andemphasized that such support should be challenged. Regarding the proposed investments, it is recommended to take the America'said (capital investment, externaldebt/ credit, foreignaid) and refuge experience. 
Keywords: Turkey, USA, Thornburg Report, Imperialism, Planning

\section{GİRIŞ}

Türkiye ile Amerika arasındaki ilişkilerin temeli Osmanlı Devleti dönemine dayanmaktadır. Amerika, ilk defa 18 Ekim 1820 tarihinde Loter Yeradis adındaki bir temsilcisini Osmanlı Devleti'ne göndererek doğrudan ticaret yapma talebinde bulunmuştu. Yeradis'in teklifi reddedilmemekle birlikte olumlu bir cevap da verilmemişti. ${ }^{1}$ Buna rağmen bazı Amerikan ticaret gemileri Osmanlı limanlarına uğrayarak ticarete başlamışlardı. Amerika, 1828'de ikinci kez Osmanlı Devleti nezdinde girişimde bulunarak iki devlet arasında ticaretin geliştirilmesini istemiş ve yapılan görüşmeler sonunda 1830'da anlaşmaya varılmıştı. Yapılan anlaşmaya göre Amerikalı tüccarlar, Osmanlı Devleti'nin diğer bazı devletlere verdiği ayrıcalıklardan faydalanacaklar ve tam bir serbestlik içinde ticaret yapabileceklerdi. Buna karşılık Amerika, Osmanlı Devleti'ne savaş gemileri hibe edebilecek ya da maddi yardımlarda bulunabilecekti. ${ }^{2} \mathrm{Bu}$ tarihten itibaren büyük ölçüde Amerikan menfaatleri doğrultusunda gelişen iki ülke arasındaki ticaret hacmi, 1830'lu yıllarda 560 bin dolar civarında iken 1913 yılına gelindiğinde 25,5 milyon dolara kadar yükselmişti. ${ }^{3}$

Birinci Dünya Savaşı döneminde ise iki devlet arasındaki ilişkiler, ABD'nin İngiltere ve Fransa'nın yanında savaşa girmesinin ardından, 20 Nisan 1917'de kesilmiştir. Kesilen ilişki Milli Mücadele yıllarında yeniden tesis edilmeye çalışıldı. Eylül 1922'den itibaren sürdürülen görüşmeler sonrasında Amerikan Hükümeti'nin desteğini almış olan Arthur Chester'e ait bir Amerikan firması ile (Chester Projesi) Musul'a kadar uzanacak olan demiryolu anlaşmasının imzası atıldı. ${ }^{4}$ Demiryolunun geçeceği güzergâhın her iki tarafındaki yeraltı ve yerüstü zenginliklerin hibe edilmesi karşılığında imzalanan anlaşma, Lozan Antlaşması'nın imzalanmasından sonra proje sahiplerinin taahhütlerini yerine getiremedikleri gerekçesi ile 17 Aralık 1923'te Bayındırlık Bakanlığı tarafından iptal edilmişti. ${ }^{5}$

\footnotetext{
${ }^{1}$ Ziya Akkaya, "Türkiye- Amerika Arasındaki İlk Muahede", Siyasi İlimler Mecmuası, C.XIX, S. 219, Haziran 1949, 225- 226.

${ }^{2}$ Anlaşma metni için bak: Mecmua-i Muahedat, C. 2, Cüz 1, Hakikat Matbaası, İstanbul 1293, 3- 6.; Akkaya, "Türkiye- Amerika Arasındaki İlk Muahede", 226.; Yaşar Semiz, Türk Amerikan Münasebetleri Işığında Chester Demiryolu Projesi, Yetkin bas., Ankara 1995, 6- 7.; Fahir Armaoğlu, Belgelerle Türk Amerikan Münasebetleri, Türk Tarih Kurumu bas., Ankara 1991, 5- 16.

${ }^{3}$ Semiz, Chester Demiryolu Projesi, 16.; J. C. Hurrewitz, Türk Amerikan İlişkileri ve Atatürk, Çağdaş Düşünce Işı̆ğında Atatürk, Eczacıbaşı Vakfi yay., İstanbul 1983, 490- 491.; Başlangıcından 1914'e kadar olan dönemde iki ülke arasındaki ticari ve siyasi gelişmeler için şu kaynaklardan faydalanılabilir. Mine, Erol, Osmanlı İmparatorluğunun Amerika Birleşik Devletleri İle Yaptığı Ticaret Antlaşmaları, Konya Tarihsiz.; Armaoğlu, Belgelerle Türk Amerikan Münasebetleri; Necdet, Kurdakul, Osmanlı Devletinde Ticaret Antlaşmaları ve Kapitülasyonlar, İstanbul 1981.

${ }^{4}$ Semiz, Chester Demiryolu Projesi, 60- 63.

${ }^{5}$ Semiz, Chester Demiryolu Projesi, 88.
} 
Amerika Birleşik Devletleri ile Türkiye arasındaki ilişkilerin düzenlenmesi konusunda, 17 Şubat 1927'de iki devlet arasında diplomatik ve konsolosluk münasebetlerinin geliştirilmesi için karşılıklı olarak notalar verilmiş ve ilişkilerin düzeltilmesi yönünde anlaşmaya varılmıştı. ${ }^{6}$ İki ülke arasında 1 Ekim 1929'da Ticaret ve Seyr-i Sefain Anlaşması (Treaty Of Commerce and Navigation) imzalanmış ise de ticari ilişkiler 1929 Dünya İktisadi Buhranının çıkması ve ardından Türkiye'nin SSCB ile ticari ilişkilerini geliştirmeye başlaması yüzünde ilerleme kaydedilememişti. Ancak iki taraf da ticari ilişki kurmak konusundan vazgeçmemiş ve 1 Nisan 1939'da taraflar arasında manevi dostluk bağlarını kuvvetlendirmek ve ticari ilişkileri geliştirmek, mütekabil imtiyaz ve menfaatler bahşederek tevsi eylemek arzusu ile bir ticaret antlaşmasını imzalamışlardı. ${ }^{8}$

II. Dünya Savaşı başladığında Alman ve İtalyan baskısını önlemek için İngiltere ve Fransa ile siyasi açıdan yakınlaşmaya çalışan Türkiye, Savaş sırasında SSCB ile yaşadığı problemlerden dolayı Amerika ile de yakınlaşmaya başlamıştı. İngiltere, Türkiye üzerinde büyük çıkarları olacağını düşündüğü $\mathrm{ABD}^{\prime}$ ye Türkiye'nin stratejik ve askeri konumunun araştırılması ve ihtiyaçlarının belirlenmesi için ABD ve İngiliz delegelerinden oluşan bir karma komisyonun kurulmasını önermiştir. Gerek savaş boyunca ve gerekse savaştan sonra Türkiye ve Yunanistan'a doğrudan veya dolaylı olarak askeri ve ekonomik yardımlarda bulunmuş olan ABD, bu öneriye sıcak bakmıştı. Yapılan çalışmalar sonrasında ABD Başkanı Truman'ın hazırlanan yardım paketini12 Mart1847 tarihinde Kongre önünde açıklaması kararlaştırılmıştı. Bu karar Türk basınında da geniş yankı bulmuş ve “Türkiye ve Yunanistan'a Yardım Yapılması İçin Truman Kongreden 400 Milyon Dolar İstedi", "Başkan Diyor ki Türkiye'nin Bağımsız Olarak Bekasının Önemi Büyüktür"9, "Truman'ın Nutku Türkiye'de Derin Akisler Bıraktı" ;0 "Amerikalılar Demokrasiyi Korumak İçin Her Şeyi Yapmak Kararındadır" 11 gibi başliklarla kamuoyuna duyurulmuştu.

Türkiye II. Dünya Savaşı öncesinde ekonomisinde devlet öncülüğünde yürütülen bir karma iktisadi politikayı uygulamaya başlamış, iktisadi kalkınma için gerekli altyapıyı hazırlamıştı. Fakat II. Dünya Savaşı'nın başlamasıyla birlikte muhtemel bir savaş ihtimali yüzünden imkânlarının çok üzerinde bir askeri güç bulundurmak zorunda kalması yüzünden ekonomisi zora girmiş, tarafsızlık politikasını uygulamaya çalışırken de dış dünya

\footnotetext{
${ }^{6}$ İsmail, Soysal, Tarihçeleri ve Açıklamaları ile Birlikte Türkiye'nin Siyasal Antlaşmaları (1920- 1945), C. 1, Türk Tarih Kurumu Basımevi, Ankara, 1989, 328- 335., Armaoğlu, Belgelerle Türk Amerikan Münasebetleri, 110- 111.

${ }^{7}$ Armaoğlu, Belgelerle Türk Amerikan Münasebetleri; 113- 116.; C. Grew, Turbulent Era: A Diplomatic Record of Forty Years; 1904-1945, vol. II. Boston: Houghton, Mifflin, 1952, 798- 99.

${ }^{8}$ Armaoğlu, Belgelerle Türk Amerikan Münasebetleri; 117- 124.

${ }^{9}$ Ulus,: 13 Mart 1947.

${ }^{10}$ Ulus,: 14 Mart 1947.

${ }^{11}$ Ulus,: 17 Mart 1947.
} 
ile ilişkileri zayıflamıştı. Bu problemlerin bir ölçüde olsun giderilebilmesi ve savaş sonrasında oluşacak Yenidünya düzeninde yerini alabilmek için tarım, sanayi, ulaşım, denizcilik vb. alanlarda topyekûn bir inşa ve kalkınma projesini hayata geçirmek ümidi ile 1944 yılından itibaren çalışmalara başlamıştı.

Dışarıda ise II. Dünya savaşını sonuna doğru ABD'nin liderliğinde oluşturulan Yenidünya düzeninin iktisadi çerçevesi çizilmeye çalış1lıyordu. Türkiye bu çerçevenin dışında kalmamak için 1944 yılında Bretton Woods'da yapılan uluslararası para ve finans konferansına katılmıştı. ${ }^{12}$ Konferansta, uluslararası iktisadi ilişkilerin yönetilmesi, bu ilişkilerde istikrarın sağlanması ve II. Dünya Savaşı'nın çıkmasına yol açan iktisadi milliyetçiliğin yükselişi üzerinde kontrolü sağlayacak olan kurumların kurulması düşünülmüş ${ }^{13}$ ve bu doğrultuda Uluslararası Para Fonu (IMF) ve Uluslararası Yeniden Yapılandırma ve Kalkınma Bankası'nın (IBRD: Dünya Bankası) kurulması kararlaştırılmıştı. SSCB dişında Birleşmiş Milletlere üye 22 Temmuz 1944'de onayladı̆̆ı anlaşma ile IMF ve IBRD' nin statüleri de belirlenmişti. ${ }^{14}$

Bu süreçte Türkiye, gelişen dünya ekonomisine ayak uydurabilmek ve dış yardımın alınmasına imkân sağlayacak bir iktisadi kalkınma programının hazırlanmasına karar vermişti. Çalışmayı Maliye Bakanı Nurullah Esat Sümer, Ekonomi Bakanı Fuat Sirmen, Ticaret Bakanı Celal Siren ve Tarım Bakanı Şevket Reşat Hatipoğlu'na bağlı bakanlıklar arası bir komisyon yürütecekti. Komisyon başkanlığını Nihat Odabaşoğlu, sekretaryayı Ekonomi Bakanlığ 1 Sanayi Tetkik Heyeti Reisi Şevket Süreyya Aydemir yürütecekti. ${ }^{15}$ Hazırlanan plan taslağı “İvedili Sanayi Planı” başlığıyla 7 Mayıs 1945'te Hükümete sunulmuştu. ${ }^{16}$

Rapor, Hükümet tarafından gözden geçirildikten sonra Avrupa Kalkınma Programının kapsamına alınmak talebi ile Amerikan iktisat uzmanlarına da sunulmuştu.

Ancak Amerikalılar bu taslağı devletçilik niteliği ön planda olduğu ve SSCB'nin planlamacı iktisadi politikasını yansıttığı gerekçesi bu planlama yöntemi ile Türkiye'nin Batı dünyası iktisadi politikası ile uyum içerisinde olamayacağını belirtmişlerdi. ${ }^{17}$ Amerikalıların

\footnotetext{
${ }^{12}$ Namık Zeki. Aral, “BrettonWoods”, Siyası İlimler Mecmuası, S. 187, Ekim 1946, 845-848.

${ }^{13}$, F. Nuray Altuğ, İstikrar Politikalarl ve Ülke Örnekleri, Türkmen Kitabevi, İstanbul, 2001, 123.

${ }^{14}$ Sinan Sönmez, Dünya Ekonomisinde Dönüşüm: Sömürgecilikten Küreselleşmeye, İmge Kitabevi, Ankara, 1998, 305.

${ }^{15}$ Şevket Süreyya Aydemir, İkinci Adam, C. 2, (1938- 1950), Remzi Kitabevi, İstanbul, 2011, 387- 389.

${ }^{16}$ Raporda, savaş sonrası ekonomisi için sanayi, madencilik, elektrifikasyon, gümrük siyaseti ve hukuk alanı ile ilgili oldukça kapsamlı bilgiler yer alıyordu. (Aydemir, Íkinci Adam., s. 403-414). Şevket Süreyya Aydemir, rapor ile ilgili CHP Genel Sekreteri Memduh Şevket Esendal'a bilgi verirmiş ve Sovyet Hafif Sanayi Komiserliğinin hazırladığı ve Türkçeye de çevrilen kitabından da bahşetmişti. Kitapla ilgili Esendal'dan şu cevabi almıştı: "Rusya'yı bırak, onu artık unutalım. Bundan sonra Rusya'nın 50 sene adı duyulmayacaktır", (Aydemir, İkinci Adam, 339).

${ }^{17} \mathrm{Bu}$ durum bundan böyle Türkiye'nin iktisadi politikasını ABD’nin istek ve eğilimlerine uygun biçimde düzenlemeye başladığı bir dönemin başladığını ortaya koymaktadır. Korkut Boratav, Türkiye'de Devletçilik, Gerçek Yayınları, İstanbul, 1974,
} 
İvedi Kalkınma Programını Batı Dünyası ile uyumlu kalkınmanın sağlanması ve Amerikan yardımının alınması bakımından yeterli bulmaması üzerine Başbakan Recep Peker, 5 Yıllık Plan taslağını Ekonomi Bakanlığına iade etmiş ${ }^{18}$ ve iç ve dış çevrelere daha yatkın gelebilecek yeni bir kalkınma planının hazırlanmasına karar vermişti. Bu kez görev liberal görüşleri ile bilinen İktisat Vekâleti Baş Müşaviri Kemal Süleyman Vaner başkanlığındaki bir heyete verilmişti. ${ }^{19}$ Heyete planın hazırlanması sırasında ana hedeflerle ilgili herhangi bir kesin talimat verilmemiş, ancak kredi temini amacıyla dış ekonomideki gelişmelerin göz önünde bulundurulması istenmişti. ${ }^{20}$ Nitekim Vaner başkanlığında hazırlanan raporda, Türkiye'yi ABD'nin beklentilerine yakınlaştıracak şekilde tarım ve bayındırlık ön plana çıkarılmıştı. Kemal Süleyman Vaner, planını hazırladığı sırada 11 Mart 1947'de Uluslararası Para Fonu'na (İMF) ve Dünya Bankası'na üye olunmuştu. ${ }^{21} \mathrm{Bu}$ gelişmelerin ardından Türkiye, Amerika'nın yapacağı Marshall Planı kapsamına alınmıştı, Amerikan Senatosunun verdiği onayın ardından bir ABD heyeti yardım programına ilişkin görüşmeler için Türkiye'ye gelmişti. Yapılan görüşmelerin ardından 4 Temmuz 1948 tarihinde Ankara'da imzalanan anlaşma ile iktisadi yardıma başlanmıştır. ${ }^{22}$

Aynı yıl Amerika'da faaliyet gösteren Yirminci Asır Vakfı'nın (The Twentieth Century Fund) temsilcisi, Türkiye'nin İktisadi Tetkiki Bürosu Müdürü ve Standart Oil Firması'nın Başmühendisi olan Max W. Thournburg başkanlığındaki bir grup uzman, ABD yardımlarının kullanım biçimini belirleyecek bir rapor hazırlamak amacıyla Türkiye'ye davet edilmişti. ${ }^{23}$ Thornburg heyetinin hazırladığı raporun hemen ardından Türkiye ile ABD arasında 8 Ekim 1948'de Marshall yardımı ile ilgili protokol imzalandı. Bu çalışmada, Max Weston Thornburg başkanlığındaki heyetin Türkiye için hazırladığı rapor incelenerek raporun tesirleri değerlendirilecektir.

\section{THONBURG RAPORU}

Türkiye İkinci Dünya Savaşı'nın son yılından itibaren bir taraftan iktisadi açıdan hızlı kalkınmanın sağlanabilmesi için projeler hazırlamaya başlamış diğer taraftan da ekonomisini Batı Dünyası ile uyumlu hale getirebilmek için Uluslararası Para Fonu'na (IMF) ve Dünya

361.

${ }^{18}$ Aydemir, İkinci Adam, 419.

19 İlhan Tekeli- Selim İlkin, Savaş Sonrası Ortamda 1947 Türkiye İktisadi Kalkınma Planı, Ortadoğu Üniversitesi Yay., Ankara, 1981, 7.

${ }^{20}$ İlker Parası, Türkiye Ekonomisi 1923 'ten Günümüze İktisat ve İstikrar Politikaları, Ezgi Kitapevi Yayınları, Bursa, 1998, 73.

${ }^{21}$ Hüseyin Şahin, Türkiye Ekonomisi, Ezgi Kitabevi, Bursa, 2002, 58.

${ }^{22}$ Haluk Ulman, Türk Amerikan Diplomatik Münasebetleri (1939- 1947), Ankara Üniversitesi Siyasal Bilgiler Fakültesi yay., Ankara, 1961, 119 .

23 “Amerikan Heyetinin Türkiye Ekonomisi Hakkındaki Görüşleri”, Türk Ekonomisi, Sene: 5, S. 50, Ağustos $1947,257-259$. 
Bankası'na da üye olmuştu. Bu süreçte sadece kendi imkânları ile sosyal, iktisadi açıdan kısa zamanda kalkınmanın sağlanamayacağı anlaşılmış ve makine ve teçhizat için dışarıdan yardım alınmasına ihtiyaç duyulmuştu. ${ }^{24} \mathrm{O}$ dönemde ABD özellikle İkinci Dünya Savaşı'nda zarar görmüş gelişmekte olan ülkelere Marshall Planı adı altında yardımda bulunma kararı almıştı. Türkiye de bu kapsamda hem ekonomisini güçlendirmek hem de İkinci Dünya Savaşı'ndan sonra oluşan Sovyet (Rus) tehdidini etkisiz hale getirmek için ABD'den yardım talebinde bulunmuştu. ABD, yardım talebinin yerinde incelenmesi amacıyla 1947 yılının başından itibaren Türkiye'ye incelemelerde bulunmak için askeri ve iktisadi uzmanlardan oluşan heyetler göndermeye başlamıştı. ${ }^{25}$

Max Weston Thornburg da bu amaç doğrultusunda Amerika'daki, Türkiye İktisadi Tetkik Bürosu Müdürü ve New York'ta bulunan Yirminci Asır Fonu'nun²6 temsilcisi sifatıyla Hükümetinin bilgisi dâhilinde Basın Yayın Genel Müdürlüğü tarafından gayrı resmi olarak ekonomik incelemelerde bulunmak üzere Türkiye'ye davet edilmişti. ${ }^{27}$ Max Weston Thornburg, Graham Spry ve George Seule'den oluşan heyet, Amerika tarafından Türkiye ve Yunanistan'a yardımda bulunmasına dair ilk teklifler dile getirilmeden önce 1947 yılı Mart ayının ortalarında Türkiye'ye gelmişti. ${ }^{28}$ Yaklaşık altı hafta Türkiye' de kalmış ve hükümet tarafından görevlendirilen yetkililer tarafından gezdirilmişti. ${ }^{29}$ Thornburg, raporun önsözünde hükümetinin bilgisi dâhilinde davet edildiğini şu şekilde ifade etmektedir: “...Bu kitapta Bakanlar veya ilgili diğer sorumlu hükümet makamlarıla açıkça mülahaza edilmemiş hiçbir kanaat ve şüphesiz ki hiçbir önemli tenkit yoktur. Amerikan görüşlerini göz önünde bulundurmak şartı ile Birleşik Amerika'nın Türk ekonomisinin ıslahına yardımda bulunup bulunmayacağı, bulunabileceği takdirde ne gibi yardımlara ihtiyaç duyulacă̆g ve bunun nasıl tatbik edileceği konusunda vereceği kararlarda ön verileri să̆lamaktır"30

\footnotetext{
${ }^{24}$ Aynı tarihlerde Sovyetler Birliği tehdidi sebebiyle Amerika'dan askeri yardımın alınması da gündemdeydi.

${ }^{25}$ Amerikan resmi heyetleri 1 Haziran 1947'den itibaren Türkiye'de incelemelere başlamışlard. Amerikan heyetinin Türkiye'de çalışmalara başlaması basında "Ankara'da Amerikan Heyetinin Tetkikleri" başlığı ile kamuoyuna duyuruldu. Cumhuriyet, 30 Mayıs ve 1-2 Haziran 1947; Akşam, 15 Haziran 1947.

${ }^{26}$ Yirminci Asır Vakfı, ABD’nin iktisadi ve sosyal konular etrafında bilimsel çalışmaları ile tanınmış bir araştırma kuruluşudur. Bu Kuruluş, Birleşik Amerika'nın II. Dünya savaşından sonra iktisadi bakımdan geri kalmış ülkelerin kalkınmalarına yardım etmek maksadıyla geniş bir program tatbikine başlayınca bu program çerçevesinde yer alan memleketlerin gerçek durumlarını ve bundan sonraki ihtiyaçlarını tespit etmek üzere faaliyet göstermektedir. Thornburg Max Weston, Türkiye Nasıl Yükselir, Çev.Semih Yazıcıŏlu, Nebioğlu yay., İstanbul (Tarihsiz), 9; Hüseyin Yayman, Türkiye'nin İdari Reform Politiği, (Doktora Tezi, Ankara Üniversitesi, 2005), 118.

${ }^{27}$ Başbakanlık Cumhuriyet Arşivi (BCA). 30. 10. 00. 00. 26. 245. 23, 26 Nisan 1947 tarihli İstatistik Umum Müdürlüğünün Başbakanlık katına yazdığı yazı.

${ }^{28}$ Max Weston Thornburg, "Amerikan Gözüyle Türkiye- Türkiye'nin Başlıca Dört Davası”, Türkiye İktisat Mecmuası, Mayıs 1948, 4, 12- 14.; Yirminci Asır Vakfı Başkanı Evans Clark'ın önsözü.; "Türkiye: Ekonomik Bir Tahlil”, adlı eserden hülasalar, Siyasi İlimler Mecmuası, C., XIX, S., 219, Haziran 1949, 117.

${ }^{29}$ Osman Okyar, "Mr. Thornburg ve Türk Ekonomisi" İstanbul Üniversitesi İktisat Fakültesi Mecmuast, C. 9, No. 4, Temmuz 1948, 288.

${ }^{30}$ Thornburg, Türkiye Nasıl Yükselir, 14.
} 
Thornburg, Türkiye'ye geliş sebebini 30 Haziran 1947'de İzmir Ticaret Odası'nda şehirdeki tüccarlarla yaptığı sohbet toplantısında şu şekilde açıklamıştır: “New York'taki Yirminci Asır Fonu isimli bir teşkilat namına gayrı resmi olarak ekonomik incelemelerde bulunmak üzere Türkiye'ye geldim. Üç buçuk aydan beri memleketinizde bulunuyor ve ekonomik tetkikler yapıyorum. Türkiye'ye tamamen yabancı değilim. Bu beşinci gelişimdir. Türkiye'nin yaşam ve ekonomik seviyesini nasıl yükseltebiliriz diye düşünüyoruz. Amerikan halkı Türkiye ile son derece alakadardır. Fakat Türkiye hakkında bir şey bilmiyorlar. Memleketime döndüğümde intibalarımı bir kitapta neşrederek Türkiye'yi Amerikahılara tanıtmaya çalışacağım... Türkiye'nin ekonomik durumunu tetkik etmek aklımdan geçmez. Yalnız görüp, öğrenmeye geldim... Öğrenmek istediğim birçok şey var. Bunları öğrenmeden Amerika'ya yanlış fikirlerle dönmek istemem" dedikten sonra öğrenmek istediklerini dört madde halinde özetlemiştir. ${ }^{31}$

1. Türkiye' de niçin yol yok?

2. Sulama tertibatınız niçin yok? Sulamadan istifade ederek ürününüzü 5-10 kat arttırabilirsiniz.

3. Dünyanın en iyi sebze ve meyve yetiştirebilecek memleketi olabileceğiniz halde konserve fabrikaları görmedim. Bu hususta bir çalışma da mevcut değil.

4. Türkiye'de niçin hususi teşebbüs yok? Hükümetin pek çok şeyi yaptığını gördüm. Neden bunları hususi teşebbüsler yapmıyor?

Thornburg, 8 Temmuz 1947'de Amerikan haber bürosunda basına verdiği demecinde de incelemeleri hakkında bilgi vermiştir. Bu toplantıda şahsına ait fikirlerden bahsederken Türkiye'de özel teşebbüsün gelişmesine imkân tanıyacak bir gelişmeyi görmediğini, eğer Türkiye ferdi ve milli bir hürriyet elde etmek istiyorsa tam anlamı ile Amerika'daki gibi olmasa da kendi şartlarına uygun usullerde bir hürriyeti benimsemesi gerektiğini ifade etmiştir. ${ }^{32}$

Benzer ifadeler Thornburg ve ekibi tarafından kaleme alınan ve Semih Yazıcıoğlu tarafından dilimize kazandırılan "Türkiye Nasıl Yükselir" adındaki eserin önsözünde de yer almaktadır. "Türkiye bizim (Amerika'nın) milli siyasetimizin gaye edinmiş olduğu bir ferdi ve milli hürriyeti elde etmeyi arzuluyorsa muhakkak surette bizimkilere uymasa bile kendi hal ve şartlarına en uygun olan usulleri kabul ve tatbik etmelidir. Türkiye hürriyeti arzulamıyorsa Amerikan yardımının gerek Türk ve gerekse Amerikan siyasetine bir faydası olmayacaktı""33

\footnotetext{
${ }^{31}$ Demokrat İzmir, 1 Temmuz 1947; Türkiye Ekonomisi, Ağustos 1947, 257.

${ }^{32}$ Ulus, 9 Temmuz 1947.

${ }^{33}$ Thornburg, Türkiye Nasıl Yükselir, 14, Truman doktrinine bakıldığı zaman da benzer ifadelere rastlamak mümkündür. Doktrin ve arkasındaki Amerikan yardımının temelinde Türkiye, Yunanistan gibi gelişmekte olan ülkelerde "demokrasiyi korumak ve kurtarmak" vardır. ***,Cumhuriyet, 7 Haziran 1947; Nihat Erim, “Amerika'nın Kararlı Durumu”, Ulus, 13 Mart 1947; Ulus, 17 Mart 1947.
} 
$\mathrm{Bu}$ açıklamaları ile daha raporunu yayımlamadan Türkiye'de geniş çaplı bir tartışmayı da başlatmış oldu. Demokrat İzmir gazetesinde Hüsamettin Petek, Thornburg'un anlattıklarından hareket ederek onu destekler nitelikte kaleme aldığ1 yazısında şunları söylemiştir: "Amerikalı, bizim her gün okuduğumuz fakat bir türlü anlamadığımız sorular sormuştur... Uzman gözü ile kim bilir neler görmüş neler düşünmüştür. Fakat ne görürse görsün en başta gördü̆̆̈̈ noksan kanaatimce devletçilik bakımından iktisadi programsızh̆̆ı̆mı ve şahsi teşebbüs genel mana bakımından birbirimize ve hükûmetin koruyuculuğuna güvensizlik ve tekel hâkimiyetinden korkumuzdur"34

İstanbul Dergisi ise Thornburg'un basın açıklamalarındaki fikirlerin büyük bir kısmına katılmadığını yazmıştır. Basın açılamasında dile getirdiklerinin önemli bir kısmının kendi memleketinde dahi halledilemeyen ve her memlekette ancak mahalli şartlara göre halledilebilecek olan sosyal ve iktisadi konular olduğunu belirtmiştir. Thornburg'un"sistem" dediği şeyi ve ona dayandırdığı tavsiyeleri de beğenmeyen dergi "Thornburg'un ifadeleri Devletçilik sistemimiz aleyhine kaba bir zorlamadır. Hazırladığın söylediğ $i$ rapor, memleketimizdeki iktisadi çalışmaların ve çalışma şartlarının tam tetkiki değil, Türk ekonomisinin liberal esaslar dâhilinde yeniden tanzimi" 35 fikrine dayanmakta ve iç işlerimize müdahale niteliğini taşımakta olduğunu belirtmiştir.

Türkiye'de raporla ilgili ilk ciddi inceleme Osman Okyar tarafından İstanbul Üniversitesi İktisat Fakültesi Dergisi'nde yayımlanan "Mr. Thornburg ve Türk Ekonomisi" adlı makalede yapılmıştır. ${ }^{36}$ Okyar, Thornburg raporunu bazı konularda eleştirmekle beraber ${ }^{37}$, özellikle iktisadi kurumların işleyişi ile yaptığ 1 eleştirileri tamamen yerinde görmektedir. ${ }^{38}$

Yirminci Asır Vakfı Direktörü Evans Clark, vakıf için yapacağı görevlerde fevkalade bir kabiliyet ve tecrübe sahibi olduğunu belirttiği Thornburg'u şu şekilde tanıtmaktadır: "Uzun yıllar Californiya Standart Oil Company Mühendisler meclisinin başkanlığını ve aynı şirketin Orta ve Uzak Doğu şubelerinin başkan yardımcılığını yapmış olmasından dolayı dış ülkelerdeki sanayi gelişmelerini iyi bilmektedir. Aynı zamanda Birleşik Amerika Dışişleri Bakanlığı'nın Petrol Müşaviri olarak dış iktisadi siyasi meseleler konusunda uzmandır"39

\footnotetext{
${ }^{34}$ Hüsamettin, Petek, "Mr. Max Weston Thornburg'un Bizi Görüşü Etrafinda”, Demokrat İzmir, 4 Temmuz 1947.

35 “Mr. Thornburg'la Aynı Fikirde Değiliz”, Ístanbul, Yıl 4, Yeni seri No. 7 Temmuz 1947, 12- 13.

${ }^{36}$ Osman Okyar, "Mr. Thornburg ve Türk Ekonomisi",Istanbul Üniversitesi İktisat Fakültesi Mecmuası, C. 9, S. 4, Temmuz 1948, 288- 303. Aynı makalenin İngilizcesi, aynı dergi, s. 268- 284. Derginin üzerindeki yayım tarihi 1948 olmasına karşılık gecikmeli olarak 1949 yılında yayımlanmış olmalı. Çünkü Okyar' ın incelediğini belirttiği raporun yayım tarihi 1949 yılıdır. Bak. Okyar, "Mr. Thornburg ve Türk Ekonomisi”, dipnot 1. Türkçe metin, 288; İngilizce metin,268

${ }^{37}$ Okyar, "Mr. Thornburg ve Türk Ekonomisi”, 290.

${ }^{38}$ Okyar, "Mr. Thornburg ve Türk Ekonomisi”, 288- 303.

${ }^{39}$ Thornburg, Türkiye Nasıl Yükselir, 12.
} 
Thornburg ve ekibi, Türkiye'de yaptıkları incelemelerin sonuçlarını 1949 yılında "Turkey and Economic Appraisal", adı ile kendisini Türkiye'ye gönderen Yirminci Asır Vakfı tarafından 27 Haziran 1949'da New York'ta yayımlanmıştır. Eser bir yıl sonra Semih Yazıcıoğlu tarafından "Türkiye Nasıl Yükselir" başlığı ile Türkçeye çevrilerek Nebioğlu yayınevi tarafından basılmıştır.

Rapor dokuz bölümden oluşmaktadır. Raporun birinci bölümü, Memleket ve Halk, İkinci bölümü Milli Mücadele ve Türkiye'de milli düşüncenin nasıl yükseldiği, üçüncü bölümü ziraata, dördüncü bölümü taşıt ve ulaştırmaya, beşinci bölümü maden kaynaklarına, altıncı bölüm enerji kaynakları ve gelişimine, yedinci bölüm ise ekonomi ve maliye konularına ayrılmıştır. Çalışmanın sekizinci bölümü genel özet, tenkit ve kıymet takdirine, dokuzuncu bölüm ise Türkiye'ye yapılacak Amerikan yardımı konusunda tavsiyelere yer verilmiştir.

Raporun "Memleket ve Halk" başlığını taşıyan birinci bölümünde Türkiye' nin fiziki, stratejik ve kültürel yapısı ile ilgi genel bilgiler verildikten sonra "Türklerin beşte dördü köylerde yaşar ve ziraatla meşgul olur. 40 bin köy bin seneden beri hiç değişmemiştir. Bu köylerde $M$. Ö. 3 bin senesinde Sümerlerin resimlerini yapmış oldukları parmaklıksız tekerlekli kă̆nıyı, kadim karasabanı görürsünüz. İnsanların yaşadıkları kulübeler gözle pek görülmez... Köylerde yol olmadığ ve yol adı verilenlerin çoğu düpedüz bir patika olduğu için mahsulleri taşımak hususunda öküz arabası ve merkeplerden başkası işe yaramaz" 40 "Bir millet olarak Türkiye vasattan da aşağı bir seviyede yaşıyor" 41 diyerek Türkiye'nin çok geri kalmış olduğunu anlatmıştır. Avrupa'da sanayi hızla gelişirken Türkiye' de bu alanda hiçbir gelişme olmadığını belirtmiştir. ${ }^{42}$

Eserin İkinci bölümü, Milli Mücadele Döneminde Türkiye'de milli düşüncenin nasıl yükseldiği ile başlar. Ardından izlenen milli iktisat politikası değerlendirilir. 1930’lardan itibaren uygulanmakta olan devletçilik politikasının bir zaruretten dolayı uygulanmaya başlandığını ifade etmekle beraber, uygulamada sıkıntıların olduğunu belirtmiştir. ${ }^{43}$ Oluşan problemlerin kaynağını devleti kuranların kimliklerine bağlayarak "İnkılâbı yapanlar ve şimdi memleketi idare etmekte olanlar Osmanlı İmparatorluğu'nda hâkim sınıfi temsil etmiş olan ailelerden yetişmişlerdir... Kudretlerini ve ekonomik üstünlüklerini başkalarıyla paylaşmak hususunda en ufak bir temayül göstermekten çok uzak kalmışlardır"44 diyerek belirtmiştir.

\footnotetext{
${ }^{40}$ Thornburg, Türkiye Nasıl Yükselir, 18 ve s. 50.

${ }^{41}$ Thornburg, Türkiye Nasıl Yükselir, 25.

${ }^{42}$ Thornburg, Türkiye Nasıl Yükselir, 25.; Z. Y. Hershlag, Turkey The Challenge Of Growth,Leiden- E. J. Brill 1968, 125.; Cahid Tanyol 1955 yılında yazdığı yazısında Thornburg'un tespitlerinin Türkiye için üzücü fakat doğru olduğunu yazar. Cahid Tanyol, “Türkiye Nasıl Kurtarılabilir? Türkiye Nasıl Yükselir?”,Cumhuriyet, 25 Mart 1955.

${ }^{43}$ Hershlag, Turkey The Challenge Of Growth, 124.; Morris Singer, The Economic Advance of Turkey, 19381960, Ayyıld1z Mat., Ankara 1977, 56- 57.

${ }^{44}$ Thornburg, Türkiye Nasıl Yükselir, 44.
} 
SSCB ile yapılan ekonomik işbirliğine şüphe ile yaklaşmış ve uygulanmakta olan Devletçilik politikasından, Komünizmin iktisadi politikasını yaklaşan melez bir uygulama olarak değerlendirmiştir. ${ }^{45}$ Bununla birlikte İktisadi faaliyette devlet tarafından oynanan geniş role ve I. ve II. beş ylllık planların kabul ve tasdikine rağmen, Türkiye ile SSCB arasında önemli hiçbir benzerlik olmadığını ve Cumhuriyet Halk Partisi liderlerinin komünist olmadıkları gibi, Marksist felsefeye de taraftar olmadıklarını ifade etmiştir. ${ }^{46}$

Thornburg, gezip gördüğü ve yetkililerden aldığı bilgiler ışığında Türkiye' nin coğrafi yapısının ziraat için oldukça elverişli olduğunu belirtmiştir. Ancak yol ve teknik imkânların eksikliği yüzünden Devletin öncülüğünde kurulan "Devlet Üretme Çiftlikleri" dışında ziraatın ilkel yöntemlerle yapıldığını belirtmiştir. ${ }^{77}$ Üretimin arttırılabilmesi için bazı teknik aletlerin üretilip kullanılmasını önermiştir. ${ }^{48}$ Bununla birlikte yol problemi çözülmeden hiçbir işin başarı ile sonuçlandırılmasını mümkün görmemiştir. ${ }^{49}$

Türkiye'nin sanayileşme konusunda sağlıklı bir planlamaya sahip olmadığını, her zaman muayyen bir planı gerçekleştirmekten ziyade, şimdi birer kâğıt kıymetinde olan programlar uygulamaya kalktığını, bir sürü "Yüksek İktisat Konseyleri", "Planlama Komisyonları" kurduğunu ve hiçbir plana dayanmadan yüksekten atma beyanatla dolu bir lisanla konuşmayı tercih ettiğini anlatmıştır. "Birbirini takip eden beş yıllık planların, gerçekte ekonomik gelişmede öncü ve teşvik edici kuvveti teşkil etmekten ziyade, siyasi, askeri veya özel kaynaklardan doğduğuna ve reklam gayeleriyle umumileştirdiğine inanmak için birçok sebep mevcuttur. Türkiye planl bir ekonomi memleketi değil, sermayesinin çoğu devlet tarafindan sağlanan ve kötü idare edilen kapitalist bir ekonomi manzarası arz etmektedir 50

Thornburg, zirai alanda yetiştirdiği ürünler için konserve fabrikası bulunmayan ${ }^{51}$ Türkiye'nin, Karabük'te iyi bir planlama yapılmadan kurulduğunu ileri sürdüğü ve "bir iktisadi ucube" olarak gördüğü Demir ve Çelik fabrikasına sahip olduğuna dikkat çekmiştir. Fabrikanın esaslı bir planlama ile daha etkili bir konuma getirilebileceğini belirttikten sonra kurtarma hareketi sırasında mutlaka Amerikan yardımının alınması tavsiyesinde bulunmuştur. ${ }^{52}$

\footnotetext{
${ }^{45}$ Thornburg, Türkiye Nasıl Yükselir, 46.; Sami Güven, 1950'lı Yıllarda Türk Ekonomisi Üzerinde Amerikan Kalkınma Reçeteleri, Ezgi Kitabevi, Bursa 1989, 40.

${ }^{46}$ Thornburg, Türkiye Nasıl Yükselir, 30.

${ }^{47}$ Thornburg, Türkiye Nasıl Yükselir, 64- 65.

${ }^{48}$ Thornburg, Türkiye Nasıl Yükselir, 84.

${ }^{49}$ Thornburg, Türkiye Nasıl Yükselir, 82- 84.;Thornburg, “Amerikan Gözüyle Türkiye- 12- 14.;"Türkiye Hakkında Thornburg'un Raporu”, İktisadi Yürüyüş, 13- 15.

${ }^{50}$ Thornburg, Türkiye Nasıl Yükselir, 46.

${ }^{51}$ Thornburg, Türkiye Nasıl Yükselir, 210- 211.

52 Thornburg, Türkiye Nasll Yükselir, 107, 205- 207 ve 218.
} 
Bu doğrultuda kurulması düşünülen çelik, kimya, uçak motoru, gübre, kâğıt sanayi, büyük enerji yatırımları gibi ağır sanayi yatırımlarından vazgeçilerek yerine tarıma öncelik verilmesi, başta tırmık ve saban olmak üzere ziraat alanı gibi hafif sanayi alanlarında yatırımlar yapılmasını ve bunun için Amerika'nın önerilerinin dikkate alınmasını istemiştir. ${ }^{53}$

Türkiye'nin ekonomik gelişme konusunda özellikle yer altı kaynakları konusunda büyük imkânları bulunduğu halde bu imkânların Hükümetin uygulamalarından dolayı yerli ve yabancı özel girişimciler tarafından değerlendirilemediğini ve Türk ekonomisinin gelişmesinde pratik Amerikan yardımı için gerekli olan ilk şartın hükümetin ekonomideki rolünün yeniden belirlenmesi olduğunu ifade etmiştir. Hükümetin, halkın kendisine değil, kendisinin halka ait olduğunu, her çeşit mesuliyet ve otoritenin halk tarafından kendisine verildiğini ana demokrasi prensibinin benimsenmesi gerektiğini belirtmiştir. ${ }^{54}$

Hükümetin bazı siyasi uygulamalarının Türkiye'nin kalkınmasını engelleyici nitelikte olduğunu ve bu tür uygulamaların Amerikan yardımını geciktirdiğini ifade ettikten sonra ${ }^{55}$ yapılacak Amerikan yardımında dikkat edilmesi gereken prensipleri de şu şekilde sıralamıştır: ${ }^{6}$

1. Türk Hükümeti'nin halkının lehindeki ekonomik gelişmelerde ferdin hem ekonomik, hem de siyasi hürriyet hakkını tanıması, amme menfaati bakımından hükümet kontrolüne tabi olması ve gerekli olan yerde Devlet ekonomik faaliyetleriyle tamamlanmasını icap ettirir.

Bu yüzden:

a. Özel sermayenin ayni derecede veya daha mükemmel bir netice sağlayacak şekilde istifadeye amade bulunduğu ticari teşebbüslerde hükümet fonları kullanılmamalıdır.

b. Özel sektör, amme menfaati göz önünde bulundurularak idare olunmalıdır.

2. Sermaye, ihtisas veya malzeme gibi Amerikan kaynakları verimli sahalardan Türkiye'de üretimi engelleyen şartlar içinde kullanılmak üzere başka alanlara kaydırılmamalıdır.

a. Şayet aynı zamanda aynı gayeyi gerçekleştirebilecek Türk kaynakları memleketin herhangi bir tarafında randımansız bir şekilde kullanılıyorsa, onların muayyen bir sahada verimli bir tarzda kullanılmaları için müsait hal ve şartlar temin olunsa bile, Amerikan kaynakları Türkiye'de işe başlamamalıdır.

\footnotetext{
${ }^{53}$ Thornburg, Türkiye Nasıl Yükselir, 172 ve 226- 227.

${ }^{54}$ Thornburg, Türkiye Nasıl Yükselir, 187- 188.

${ }^{55}$ Thornburg, Türkiye Nasıl Yükselir, 134.

${ }^{56}$ Thornburg, Türkiye Nasıl Yükselir, 192- 193.
} 
b. Türkiye'de kullanılacak olan Amerikan sermayesi veya sermayeyi teşkil eden malların verimli bir şekilde kullanılabilmesi için gerekli teknik maharet veya tecrübeye sahip bulunan şahıslar işi idare etmelidir.

3. Usulü dairesinde siyasi, içtimai, iktisadi gayeler ve düzenli bir idari muamele hususunda verilecek teminat kanunda açıç̧a belirtilmelidir. Ortaya çıkabilecek görüş farklılığının çözümünde mahkemeler tam yetkili olmalıdır. Mevcut kanunlarda yapılacak ıslahatı beklerken, özel teşebbüsün korunması bazı acil durumlar için gerektiğinde özel kanunlar çıkarılabilmeli ve işler, emirlerle keyfi iptallere konu olacak her hangi bir devlet memurunun otoritesine bırakılmamalıdır.

Thornburg, her fırsatta Türkiye' de özel sektöre daha fazla firsat verilmesi gerektiğini savunmuştur. ${ }^{57}$ Ancak özel sektörde yer almaya çalışan sermayedarların sınaî bilgiden mahrum olduklarını; yetişmiş personelden oluşan kadroları oluşturabildikleri takdirde, Türkiye'de hem amme işlerinde, hem de özel teşebbüs sahalarında daha başarılı olacaklarını ve yabancı sermayeden daha çok faydalanabileceklerini belirtmiştir. ${ }^{58}$

Thornburg, raporunu kime takdim ettiğini açıkça belirtmemekle birlikte süreç göz önünde bulundurulduğunda, Recep Peker Hükümeti (7 Ağustos 1946- 10 Eylül 1947) tarafından sipariş edildiği fakat hükümet değiş̧iklikleri nedeni ile 16 Ocak 1949'da göreve gelen 59 Şemsettin Günaltay Başkanlığındaki hükümet yetkililerine teslim edildiği anlaşılmaktadır. Günaltay Hükümeti ise raporu inceleyip hayata geçiremeden, CHP 14 Mayıs 1950'de iktidarı Demokrat Parti'ye bırakmıştı. Demokrat Parti, iktidarının ilk yıllarında Thornburg raporundaki önerilenleri hayata geçirmeye gayret etmiştir.

Thornburg'un raporunda dile getirdiği demokrasinin ruhu olan kişisel hürriyetin öne çıkarılması, devletçiliğin alanının daraltılması, özel sektöre daha fazla yer verilmesi' ${ }^{60}$, ağır sanayiden vazgeçilmesi, yabancı sermayeye yatırım ortamını sağlama ve eşit hakların tanınması gibi konular 1950'den sonra büyük ölçüde hükümet politikası haline gelmişti. Demokrat Parti iktidara geldikten sonra bu konularda açılamalarda bulunan Cumhurbaşkanı Celal Bayar, 1 Kasım 1950'de Meclisin açılış konuşmasında Thornburg'un dile getirdiği konuların nerede ise tamamına değinmiştir. Memlekette umumi hukuk nizamını, demokrasinin ruhu olan hürriyet, bilhassa fert hürriyeti anlayışına göre her sahada yeniden ayarlamanın sırasının geldiğini, devletçilik konusunda bir orta yol bulacaklarını; tarımda yerli ve yabancı uzmanların dile getirdikleri konulara dikkat edilerek yeni

\footnotetext{
${ }^{57}$ Singer, The Economic Advance of Turkey, 57.

${ }^{58}$ Thornburg, Türkiye Nasıl Yükselir, 168. Thornburg, Amerika'da yeterli sayıda yetişmiş uzmanın bulunduğunu ve Türkiye'deki sermaye sahiplerinin onların danışmanlığına başvurabilecekleri önerisinde bulunur

${ }^{59} 10$ Eylül 1947'den 16 Ocak 1949'a kadar bir ve ikinci Hasan Saka Hükümeti görev yapmıştır.

${ }^{60}$ Hershlag, Turkey The Challenge Of Growth, 136.
} 
yatırımların yapılacağını ifade etmiştir. Ayrıca Devletin, ekonomik alanda endüstri kurmak ve bireylerle bütün alanlarda rekabet etmek suretiyle ekonomiye doğrudan doğruya müdahale etmesinin önüne geçileceğini ve özel teşebbüse bundan böyle öncelik tanınarak, devletin sadece özel sermayenin istenilen sonuçları elde edemediği alanlara müdahalede bulunacağını belirtmiştir. ${ }^{61}$

Başbakan Menderes de yaptığı konuşmalarda açıkça Thornburg'dan bahsetmemekle birlikte onun görüşleri doğrultusunda açıklamalarda bulunmuştur. Menderes, 29 Mayıs 1950'de yaptığı konuşmasında “Memleketimizin geniş imkânlarıla milletimizin yüksek vasıfları göz önünde tutulacak olursa uzun yilların beyhude israf edilmiş olduğuna ve hatta memleketin tabii inkişaf seyrinin hatalı ve sakat politikalarla engellenmiş olduğuna hükmetmek gerektiğini dile getirerek, eski iktidarın bu uygulamalarında süratle vazgeçileceğini" belirtmiştir. ${ }^{62}$

Demokrat Parti, Thornburg'un raporu doğrultusunda ulaşım politikasına, tarıma, hafif sanayiye yatırım yaparak iktidarının ilk döneminde belli bir başarıya da ulaştı. Ancak bir süre sonra daha ileri sanayi yatırımlarına ihtiyaç duyulmaya başlanınca Amerikan yardımının artırılıp arttırılamayacağı ve yatırımlar için yeni yol haritasının çizilmesi için o sırada Bahreyn'de bulunan Thornburg, Başbakan Menderes tarafından 21 Kasım 1953'te yeniden Türkiye'ye davet edildi. ${ }^{63}$

Thornburg, daveti kabul ettiğini Cumhurbaşkanı Celal Bayar'ın Amerika gezisi sonrasında bir mektupla kendisine iletmişti. Mektubunda, şu ifadelere yer vermiştir. "Sayın Cumhurreisi, bundan beş sene evvel New York Yirminci Asır Federasyon'u (Vakfi) beni Türkiye'nin iktisadi durumunu tetkike memur etmişti. Bu vazifeyi kabul ettiğim vakit takip ettiğim yegâne gaye Türkiye'de gördüğ̈̈m vaziyeti bana verilen talimat esasları dairesinde tespit etmekti. Arkadaşlarınla birlikte incelemelerimizi ikmal edip elde ettiğimiz neticeleri herhangi bir yanlışlı̆̆a mahal vermemek üzere bir kere de salahiyetli vekillerle gözden geçirdikten sonra raporu Federasyon'a tevdi etmiştim. Tetkikatımızın Türkiye'de lüzumundan fazla sert bulunduğunu biliyordum" dedikten sonra 1950 seçimleri ile iktidar değişikliğinden duyduğu memnuniyeti dile getirmiş ve mektubunu şu şekilde sürdürmüştü. "1950 senesinden beri memleketinizde gördüklerim, yurdunuzun muhtaç olduğu bir Hükümet Programının mevkii tatbike konulmuş olduğuna beni ikna etti. Bunun içindir ki her şeyden evvel kendi sayı ve gayreti ile inkişaf ettiğini, kendi memban ile hakiki bir demokrasiye

\footnotetext{
${ }^{61}$ Tarihe Düşülen Notlar 1, Yasama Yılı Açıllşlarında Cumhurbaşkanlarının Konuşmaları- 1(1 Mart $1924-14$ Aralık 1987), Yayın koordinatörü: Rüçhan Akıncıoğlu, TBMM yay., Ankara 2011, Cumhurbaşkanı Celal Bayar'ın 1 Kasım 1950'deki TBMM Açış Konuşması, 141- 144. Benzer İfadeler 1 Kasın 1951 tarihli konuşmada da vardır. Cumhurbaşkanı Celal Bayar'ın 1 Kasım 1950'deki TBMM Açış Konuşması, 172- 174.; Kemal H. Karpat, Türk Demokrasi Tarihi, Timaş yay., İstanbul 2010, 378- 379.

${ }^{62}$ Başbakanlarımız ve Genel Kurul Konuşmaları C. 4, Adnan Menderes, Haz. İrfan Neziroğlu ve Tuncer Yılmaz, TBMM bas., Ankara 2014, 7-8.

${ }^{63}$ BCA, 030. 01. 00. 00. 40. 238. 14. Başbakan Menderes tarafından Thornburg' a çekilen telgraf.
} 
hakiki bir demokrasiye yükseldiğini ve bu suretle devrimizin en mühim ve numune teşkil eden bir devlet olduğunuzu Amerikan milletine anlatmağı bir vazife telakki ediyorum". Thornburg, mektubunu Ocak 1954'te birkaç haftalığına Türkiye'ye geleceğini belirterek sonlandırmıştır. ${ }^{64}$

Thornburg, belirttiği gibi 1954 yılı Ocak ayında değil, Mart 1954'te Türkiye'ye geldi. Yapılan görüşmelerden sonra hükümet, Thornburg'tan Amerikan yardımının yeniden ayarlanması ve yardımın arttırılarak sanayi yatırımlarını da kapsamasını talep etti. Demokrat Parti'nin bu talebine karşılık Amerika mali ve iktisadi tedbirleri kontrol etmek şartıyla yardım edebileceğini ileri sürmüştü. Ancak Türkiye bu öneriyi kabul edilebilir bulmamışt1 ${ }^{65}$ ve yeni çözüm yolları arayışına girmişti.

Amerika ile yaptığı sanayi yatırımları konusundaki görüşmelerin tıkanma noktasına geldiği dönemde Thornburg yeniden devreye girmiş ve birkaç defa daha Türkiye'ye davet edilmiş ${ }^{66}$, görüşlerine başvurulmuş ve hükümetin iktisadi müşavirliğine getirilmişti. ${ }^{67} \mathrm{O}$ süreçte Thornburg, ekonominin yeniden sağlıklı bir şekilde büyümesini sağlamak için fiyatların kontrol edilmesi, halkın daha az sarf etmesi ve yatırımların kontrollü ve planlı yapılması gerektiğini ifade etmiştir. ${ }^{68}$ Fakat Hükümet, halkın tüketim alışkanlığına dokunmadan istihdam imkânlarını sağlamak için daha büyük çaplı yatırım yapma arayışına girmişti. Türkiye'nin bu girişimi, hem Amerika'nın hem de Türkiye'ye Amerikan yardımının zaruri olduğunu düşünen Thornburg'un eleştirilerine sebep olmuştu.

Thornburg, Hükümetin şu veya bu sebeple milli ekonomiyi henüz tam anlamiyla ayakta tutmayı başaramadığı dönemde, ileride verimli olacağı düşünülen teşebbüslere yüz milyonlarca lira yatırmayı planladı̆̆ını ve kısa vadede ödenmesi gereken borçların kaynaklarını tükettiğini belirtmiştir. Oysa yapılması gerekenin içerideki iktisadi idareyi mükemmelleştirmek değil, mevcut ekonominin ıslahını mümkün kılacak önlemleri almak olduğunu ifade etmiştir. ${ }^{69} \mathrm{Bu}$ süreçte Amerika'nın, yapacağı mali yardımı geciktirmesinin sebebinin yapılacak yardımın eski ekonomik görüşlerinde israr eden Hükümetin elinde yaşatıcı olmaktan ziyade "vakitsiz mükemmelleştirici" yani zararlı bir vasıta olması endişesinden kaynaklandığını belirtmiş ve bu zararlı gidişat durdurulmadıkça yardımın

\footnotetext{
${ }^{64}$ BCA, 030. 01. 00. 00. 40. 238. 14 Thornburg'un 21 Ocak 1954'te Cumhurbaşkanı Celal Bayar'a yazdığ1 mektup. Aynı belge numarasında Celal Bayar'a yazılan mektubun Türkçeye çevrilmiş metni de bulunmaktadır.

${ }^{65}$ Yardımın attırılması konusunda Amerikalılarla yapılan göçüşmeler, Amerikalıların Türkiye'nin mali ve iktisadi konularda alacağı tedbirleri kontrol etmek şartıyla yardımı arttırabileceklerini belirtmeleri üzerine reddedilmişti. "Reddedilen Amerikan Teklifi”,Dünya, 17 Mart 1955.

${ }^{66}$ Bazı gelişleri için bak. Cumhuriyet, 14 ve 15 Mart 1955.

${ }^{67}$ Cahid Tanyol, "MaxThornburg ve Türkiye",Cumhuriyet, 17 Mart 1955. Tanyol, Thornburg'un Türkiye'nin ekonomik ve sosyal realitesini yakından tanıyan bir iktisatçı olmasından dolayı danışmanlığa getirilmesi fikrini doğru bulmuştu. "Thornburg, İktisadi Müşavir Olarak Göreve Başliyor", Cumhuriyet, 29 Nisan 1955.

68 “Thornburg ve Türk Ekonomisi”,Dünya, 16 Mart 1955.

${ }^{69}$ Behçet Cemal, "Thornburg'un Demeci”,Dünya, 28 Mart 1956. Bu yaklaşım tarzına en ciddi eleştirilerden birisi
} 
daha da geciktirileceğini dile getirmişti. ${ }^{70}$ Thornburg, ayrıca hızla artan enflasyona karşı önlem alınması önerisinde bulunmuş ve Türkiye'de 1956 veya 1957 yılları içinde bir devalüasyon yapılmasını da doğru bulmadığını belirtmişti. ${ }^{71} \mathrm{Bu}$ açıklamalarının ardında Başbakan Menderes'le de bir görüşme yapmıştı. ${ }^{72}$

Tam da bu tartışmaların yaşandığı dönemde SSCB Türkiye'ye yeni sanayi yatırımları yapmak ve var olanları da geliştirmek için geri ödemesi 20 yıla yayılan kredi teklifinde bulunmuştu. ${ }^{73}$ Rus teklifinin tartışıldığı sırada Thornburg, basına bir açıklama yaparak "Türkiye' ye uzun vadeli bir Amerikan yardımının zaruri olduğunu" belirttikten sonra "Amerika ya Türkiye'ye süratle ve büyük ölçüde yardımda bulunacak veya Dünyanın bu kısmında Amerikahların güvendiği yegâne kaleyi elden kaçırmak tehlikesi ile karşılaşacaktır" demişti. ${ }^{74}$

Thornburg raporu, "Devletçilik" anlayışına ters düştüğü ve ağır sanayi yatırımlarının durdurularak onun yerine küçük çaplı yatırımların yapılmasını önerdiği için ciddi şekilde eleştirildi. ${ }^{75}$ Eleştiriyi yapanların önemli bir kısmı Doğan Avcıoğlu, Yalçın Küçük gibi sol düşünceleriyle bilinen kimselerdi. Ancak Thornburg raporuna en ciddi eleştirilerden birisi 1979 yılında Dördüncü Beş Yıllık Plan'ın (1979- 1983) görüşülmesi sırasında dönemin Başbakanı Süleyman Demirel tarafından yapıldı. Demirel Türkiye'nin sanayileşmesinde bir engel olarak gördügü rapor için "Efendim bize çoban olun diyorlar, bize çiftçi olun, bakkal olun, manav olun diyorlar... Yok böyle şey. Onları bize çok evvel de dediler. Bu kürsülerde Barker raporu tartışması yaptık bundan 10 sene evvel. 1949'larda da dediler, 1950'lerde de dediler onu, 1951'lerde de dediler. Thornburg raporu tartışması yaptık. Bize dediler ki: “Siz, büyük sanayi kurmayın, küçük işletmeler kurun, tavukçuluk yapın, hayvancılık yapın, besicilik yapın; yani, çiftçilik ve çobanlık yapın. Türkiye'nin kaderini o günkü idare orada görmedi, o raporu firlattı attı"76

\footnotetext{
${ }^{70}$ Cemal, “Thornburg'un Demeci”, Dünya, 28 Mart 1956.

${ }^{71}$ Tekeli, “İktisadi Durumumuz Hakkında Bir Rapor ve Bir Demeç”, 26 Mart 1956.; Falih Rıfkı Atay,

“Thornburg'un Gazetemize Söyledikleri”, Dünya, 31 Mart 1956.

${ }^{72}$ Dünya, 30 Mart 1956.

${ }^{73}$ Amerikan teklifinin reddedildiği sırada Sovyet Rusya 20 senede geri ödenmesi şartıyla Türkiye'ye üç iplik ve dokuma fabrikası kurmak ve Kayseri'deki kombinaları iki misli büyütülmesi için kredi önerisinde bulunmuştu. “Rusya'nın Türkiye'ye Teklifleri”,Dünya, 20 Mart 1955.;"Sovyet Rusya'nın Teklifleri ve Türkiye'ye verilecek Kredi”,Tan, 24 Şubat ve 5 Mart 1956.

${ }^{74}$ Cumhuriyet, 24 Mart 1956.; Tekeli, “iktisadi Durumumuz Hakkında Bir Rapor ve Bir Demeç”, 26 Mart 1956.; Cemal, "Thornburg'un Demeci”, 28 Mart 1956

${ }^{75} \mathrm{Bu}$ eleştirilerin önemli bir kısmı için bak., Güven, 1950'lı Yıllarda Türk Ekonomisi Üzerinde Amerikan Kalkınma Reçeteleri, 25- 106.

${ }^{76}$ Türkiye Büyük Millet Meclisi Tutanak Dergisi, Dönem 5, C. 7, Toplantı 2, 8. Birleşim 22 Kasım 1978, 279.
} 


\section{SONUÇ}

Thornburg raporu, İkinci Dünya Savaşı'ndan sonra gelişen Yenidünya şartlarına uygun iktisadi politika arayışı içinde olan hükümet tarafından hazırlatılmıştır. Hazırlanan rapor, Türk ekonomisi hakkında detaylı bir tahlil yapmış olmakla beraber yapılan tahliller büyük oranda Amerika ekonomisine ve menfaatlerine uygundur. Raporun önsözünde, Türk hükümeti ile Türk halkının Amerikan yardımının etkili olacağı şekilde yapılmasını istediklerini, bu sebeple de ellerinden geldiği ölçüde Türkiye'de yardımı mümkün kılacak iç şartların oluşturulmasına çalışılması önermiştir.

Amerika'daki kadar olmasa bile Türkiye'nin de kendi dinamikleri içerisinde demokrasinin en temel kuralı olan hürriyeti ön plana çıkarması ve hür düşünceye, hür teşebbüse önem vermesi istenmiştir. Türkiye'de 1930'lu yıllardan beri uygulanmakta olan "Devletçilik" anlayışı da bu yaklaşımdan dolayı şiddetle eleştirerek Hükümete ekonomi üzerindeki kontrolünü gevşetmesi için adeta manevi baskı yapmıştır.

Thornburg, Türkiye'deki sistemi sıkı bir biçimde eleştirdiğinin farkındadır. Bu durumu isim vermeden tarif ettiği "Tanınmış bir Türk vatanseveri ve eski bir bakan ve halen hususi teşebbüs sahasında önemli bir şahsiyetin" kendisine söylediği "Düşman güldürür, dost ağlatır." atasözü ile açılamaya çalışmıştır.

Rapor dikkatle incelendiği zaman, II. Dünya savaşı sonrası dönemde ABD'nin yeni bir dış politika stratejisi belirlemeye çalıştı̆̆ı dönemde ortaya çıkan Truman Doktrini çerçevesinde Eski Dünya'ya ve özellikle Ortadoğu'ya yeni bir yol haritası eşliğinde barış ve refah getirme düşüncesinin bir ürünü olduğu da görülür. Bu tez günümüzün Büyük Orta Doğu projesi olarak adlandırılan Ortadoğu'ya demokrasi, barış ve zenginlik getirmek isteyen teze paralellik göstermektedir.

Genel bir çerçeveden bakıldığı zaman aslında Thornburg raporu, Türkiye'ye, idaresini sadece kırtasiyecilik ve gereksiz prosedürlerden kurtarmasını değil, topyekûn sistem eleştirisi yaparak bir bakıma sistem değişikliği yapılmasını önermektedir. Önerilerin bir kısmı Demokrat Parti'nin 14 Mayıs 1950'deDemokrat Parti'nin iktidara gelmesinin ardından hayata geçirilmiştir. Ancak 1952- 1956 yılları arasında Amerika'dan alınan yardımların sanayileşme yerine askeri çıkarlar için de kullanılabilecek yol, köprü, liman gibi geri alt yapı yatırımlarına gitmesi Demokrat Partiyi de rahatsız etmiş ve 1955 yılından itibaren Amerikan yardımlarını sorgulamaya başlamıştı. Bu sorgulama bir süre sonra gerçekleşecek olan 27 Mayıs 1960 darbesini hazırlayan sebepler arasında yer almıştır. 


\section{KAYNAKÇA}

\section{Belgeler:}

Başbakanlık Cumhuriyet Arşivi (BCA). 30. 10. 00. 00. 26. 245. 23.

Başbakanlık Cumhuriyet Arşivi (BCA)., 030. 01. 00. 00. 40. 238. 14.

Başbakanlık Cumhuriyet Arşivi (BCA)., 030. 01. 00. 00. 40. 238. 14.

\section{Gazeteler:}

Akşam, 15 Haziran 1947.

Cumhuriyet, 30 Mayıs 1947.

Cumhuriyet, 14 Mart 1955.

Cumhuriyet, 15 Mart 1955.

Cumhuriyet, 1 Haziran 1947.

Cumhuriyet, 2 Haziran 1947.

Cumhuriyet, 7 Haziran 1947.

Cumhuriyet, 29 Nisan 1955.

Cumhuriyet, 24 Mart 1956.

Demokrat İzmir, 1 Temmuz 1947.

Dünya, 16 Mart 1955.

Dünya, 20 Mart 1955.

Dünya, 17 Mart 1955.

Dünya, 30 Mart 1956

Tan, 24 Şubat 1956.

Tan, 5 Mart 1956.

Ulus, 13 Mart 1947.

Ulus, 14 Mart 1947

Ulus, 17 Mart 1947.

Ulus, 9 Temmuz 1947

Kitap ve Makaleler: 
Akkaya, Ziya, "Türkiye- Amerika Arasındaki İlk Muahede",Siyasi İlimler Mecmuası, C.XIX, 219., Haziran 1949.

ALTUĞ, F. Nuray, İstikrar Politikaları ve Ülke Örnekleri, Türkmen Kitabevi, İstanbul, 2001.

"Amerikan Heyetinin Türkiye Ekonomisi Hakkındaki Görüşleri”, .Türk Ekonomisi, Y11. 5, S. 50, 257-259, A ğustos 1947.

Aral, Namık Zeki, “Bretton Woods”, Siyası İlimler Mecmuası, S. 187, Ekim 1946, s. 845848), 1946.

Armaoğlu, Fahir, Belgelerle Türk Amerikan Münasebetleri, Türk Tarih Kurumu Bas., Ankara,1991.

Aydemir, Şevket Süreyya, İkinci Adam, C. 2, (1938- 1950), Remzi Kitabevi, İstanbul, 2011.

Atay, Falih Rıfkı, “Thornburg'un Gazetemize Söyledikleri”, Dünya, 31 Mart 1956.

Başbakanlarımız ve Genel Kurul Konuşmaları, C. 4, Adnan Menderes, Haz. İrfan Neziroğlu ve Tuncer Y1lmaz, TBMM bas., Ankara, 2014.

Boratav, Korkut, Türkiye'de Devletçilik, Gerçek Yayınları, İstanbul, 1974.

Cemal, Behçet, “Thornburg'un Demeci”,Dünya, 28 Mart 1956.

Erim, Nihat, “Amerika'nın Kararlı Durumu”,Ulus, 13 Mart 1947.

EROL, Mine, Osmanlı İmparatorluğunun Amerika Birleşik Devletleri İle Yaptı̆̆ı Ticaret Antlaşmaları, Konya, (Tarihsiz).

Grew, J. C., Turbulent Era: A Diplomatic Record of Forty Years; 1904-1945, vol. II. Boston: Houghton, Mifflin, 1952.

Güven, Sami, 1950'lı Yıllarda Türk Ekonomisi Üzerinde Amerikan Kalkınma Reçeteleri, Ezgi Kitabevi, Bursa, 1989.

Hurrewıtz, J. C., Türk Amerikan İlişkileri ve Atatürk,Çă̆daş Düşünce Işı̆̆ında Atatürk, Eczacıbaşı Vakfı yay., İstanbul, 1983.

“Mr. Thornburg'la Aynı Fikirde Değiliz”, İstanbul, Yıl 4, Yeni seri No., 12- 13. İstanbul ,7 Temmuz 1947.

Karpat, Kemal H., Türk Demokrasi Tarihi, Timaş yay., İstanbul, 2010.

Kurdakul, Necdet, Osmanlı Devletinde Ticaret Antlaşmaları ve Kapitülasyonlar İstanbul, 1981. 
“Mecmua-i Muahedat”, C. 2, Cüz 1, Hakikat Matbaası, İstanbul, 1293.

Okyar, Osman, “Mr. Thornburg ve Türk Ekonomisi” İstanbul Üniversitesi İktisat Fakültesi Mecmuası, C. 9, No. 4, 288- 303, Temmuz 1948

Parasız, İlker, Türkiye Ekonomisi 1923'ten Günümüze İktisat ve İstikrar Politikaları, Ezgi Kitabevi Yayınları, Bursa, 1998.

Petek, Hüsamettin, “Mr. Max Weston Thornburg'un Bizi Görüşü Etrafında”, Demokrat İzmir, 4 Temmuz 1947.

Semiz, Yaşar, Türk Amerikan Münasebetleri Işı̆̆ıında Chester Demiryolu Projesi, Yetkin bas., Ankara, 1995.

Singer, Morris, The Economic Advance of Turkey, 1938- 1960, Ay yıldiz Mat., Ankara 1977

Sönmez, Sinan, Dünya Ekonomisinde Dönüşüm: Sömürgecilikten Küreselleşmeye, İmge Kitabevi, Ankara, 1998.

Soysal İsmail, Tarihçeleri ve Açıklamaları ile Birlikte Türkiye'nin Siyasal Antlaşmaları (1920-1945), C. 1, Türk Tarih Kurumu Basımevi, Ankara, 1989.

Şahin, Hüseyin, Türkiye Ekonomisi, Ezgi Kitabevi, Bursa, 2002.

Tanyol, Cahid, ."Max Thornburg ve Türkiye”, Cumhuriyet, 17 Mart 1955.

Tanyol, Cahid, “Türkiye Nasıl Kurtarılabilir? Türkiye Nasıl Yükselir?”, Cumhuriyet, 25 Mart 1955.

Tarihe Düşülen Notlar 1, Yasama Yılı Açılışlarında Cumhurbaşkanlarının Konuşmaları-1, (1 Mart 1924- 14 Aralık 1987), Yayın koordinatörü: Rüçhan Akıncıoğlu, TBMM yay., Ankara, 2011.

Tekeli, Esad, “İktisadi Durumumuz Hakkında Bir Rapor ve Bir Demeç”, Cumhuriyet, 26 Mart 1956.

Tekeli, İlhan- İlkin, Selim, Savaş Sonrası Ortamda 1947 Türkiye İktisadi Kalkınma Planı, Ortadoğu Üniversitesi Yay., Ankara, 1981.

Thornburg, Max Weston., “Amerikan Gözüyle Türkiye - Türkiye'nin Başlıca Dört Davası", Türkiye İktisat Mecmuası, s. 4, 12- 14., Mayıs 1948.

Thornburg, Max Weston, Türkiye Nasıl Yükselir, Çev. Semih Yazıcıŏ̆lu, Nebioğlu yay., İstanbul, (Tarihsiz). 
Türkiye Büyük Millet Meclisi Tutanak Dergisi, Dönem 5, C. 7, Toplantı 2, 8. Birleşim, 279, 22 Kasim 1978.

“Türkiye: Ekonomik Bir Tahlil Adlı Eserden Hülasalar",. Siyasi İlimler Mecmuası, C., XIX, S., 219, Haziran 1949- s. 220, 152-155, Temmuz 1949.

Ulman Haluk, Türk Amerikan Diplomatik Münasebetleri (1939- 1947), Ankara Üniversitesi Siyasal Bilgiler Fakültesi yay., Ankara, 1961.

“Türkiye Hakkında Thornburg'un Raporu”, İktisadi Yürüyüş, C. 10, s. 231, 13- 15, 6 A ğustos 1949.

Yayman, Hüseyin, Türkiye'nin İdari Reform Politiği, A. Ü. Sosyal Bilimler Enstitüsü Kamu Yönetimi ve Siyaset Bilimi Anabilim Dalı, Doktora Tezi, Ankara, 2005. 


\section{EKLER}

1-Thornburg ve arkadaşları tarafından hazırlanan raporun iç kapağ 1

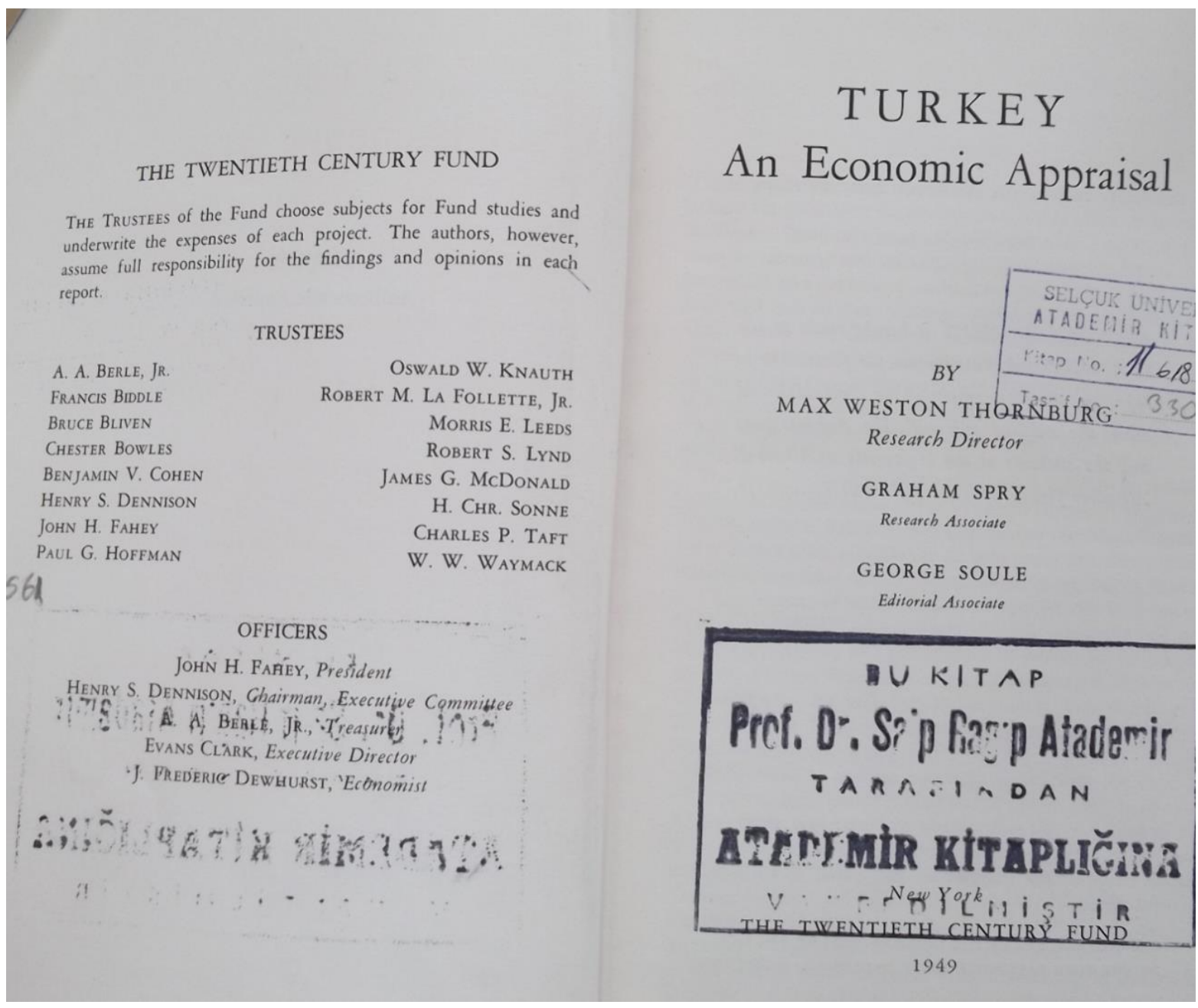


2- Thornburg'un Başvekâlet İstatistik Umum Müdürlüğünü ziyareti

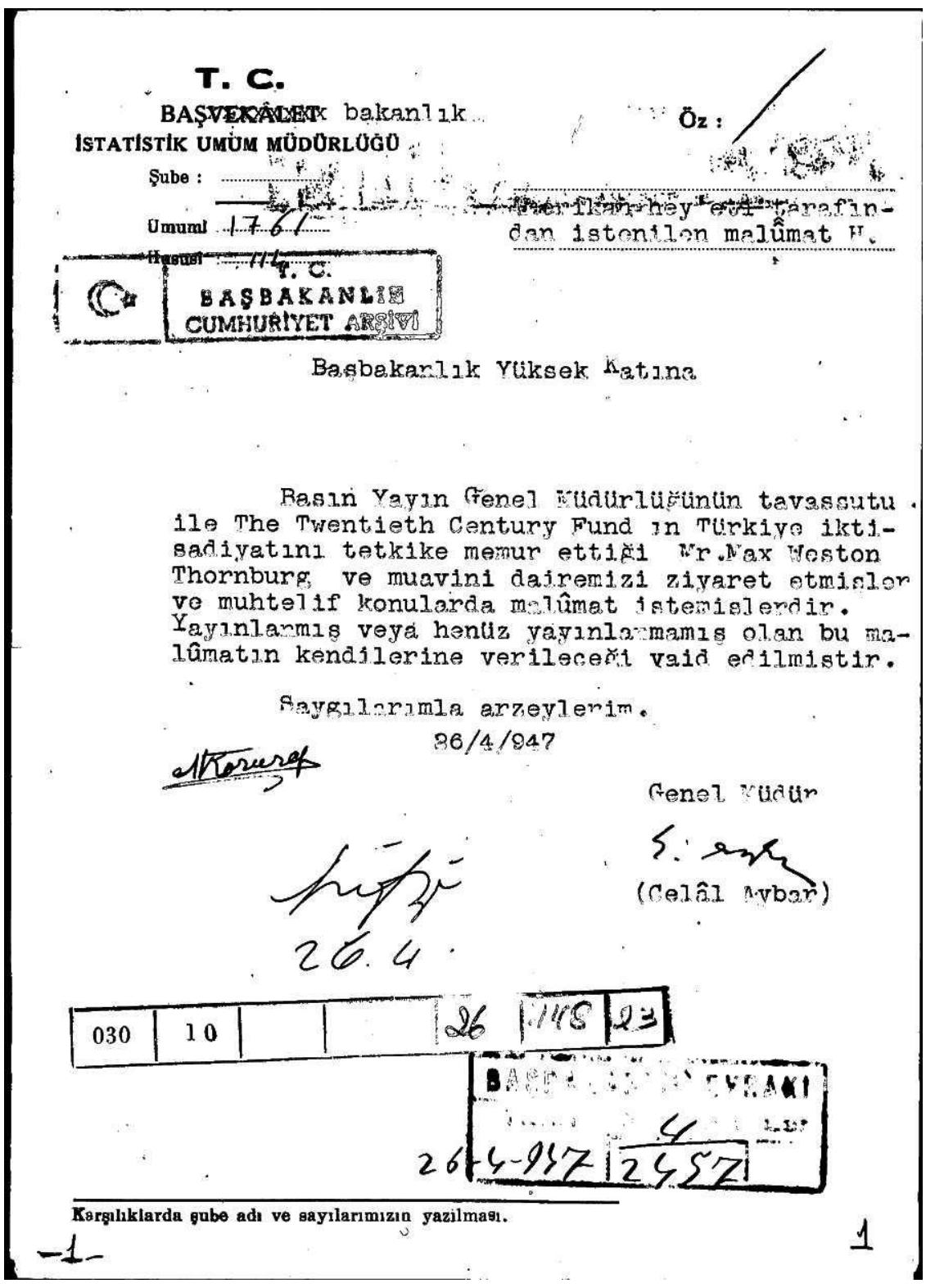


3 - Thornburg'un İzmir'i ziyareti

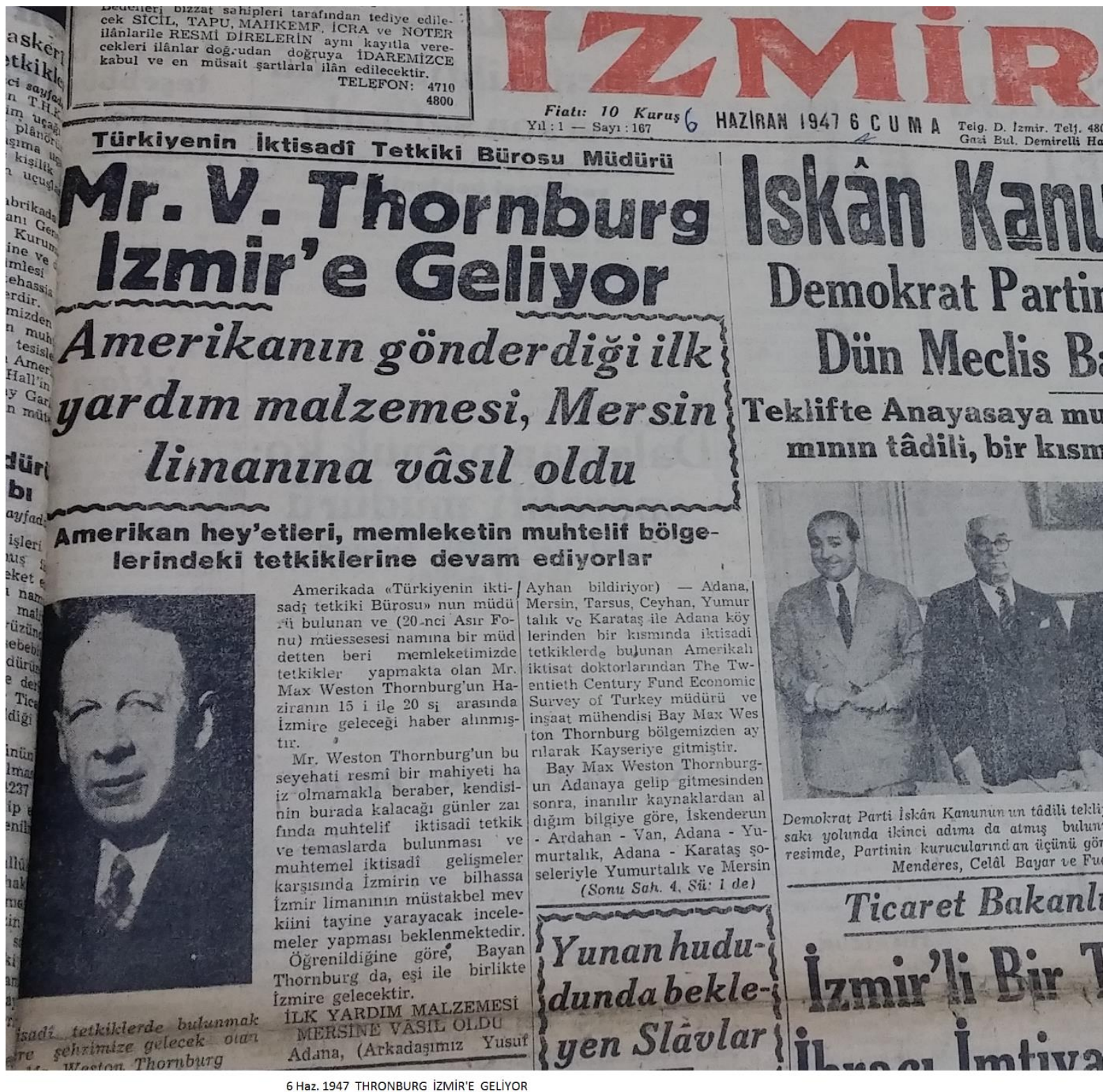


Yaşar SEMIZ, Güngör TOPLU-Cumhuriyet Döneminde Amerikan Emperyalizminin Türkiye'ye Girişi: Thornburg Raporu

3- Başbakan Menderes' in “1953'te Thornburg'u Türkiye'ye davet eden telgrafı.

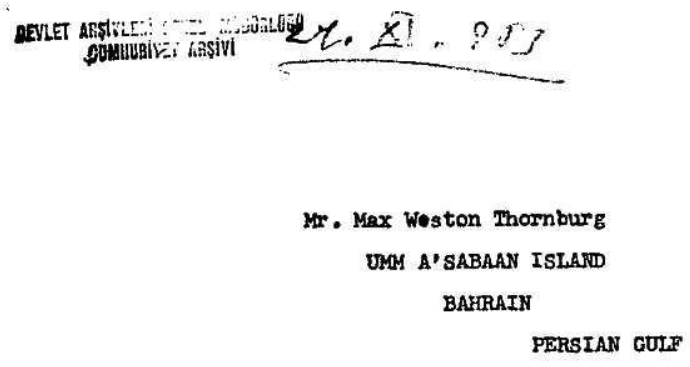

Heve been informed of contents your letter october 21 addressed to President stop will be pleased of your visit to our country at an oarly date before end January stop Turkfsh Government will be glad Indicate competent persons and extend assistance for preparation of your projected articl. stor please cable dúte of arrival stop best regracis

Adnan Menderes Prime Minister

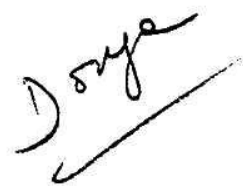

.5.

\begin{tabular}{|l|l|l|l|l|l|l|}
\hline 030 & 01 & & 40 & 238 & 14 \\
\hline
\end{tabular}


4- Thornburg'un 21 Ocak 1954'te Cumhurbaşkanı Celal Bayar'a yazdığı mektup. +3 .

MAX WESTON THORNBURG

MOREIGN INOUSTRIAL CONSULTANT

Hils Excollency Colâl Eayar,

Prosident of Turkey.

Your Excellexcy,

About five years ago the TWBITIETH GEMTJRY FURD OF NWW YORK esked to to serve ss Fiesearch Diroctor of a study thet Institution had in Iind concerning the curront scononic situation in Turkey, frox the particular point of view of determining what Americens might do, publicly or frivataly, to assist Iurisey in advencing the Progrex launched by the distlagulshod for the new Turk1sh Republic, Kenal Attaturk.

I undertook this task with the solo intention of uppraising the situation as I found it 1n Turkey accordilg to the terns of wo assignaent. Liter m associatos and I had completed our concernec, personelly revlowed ou misunderstandings, and geve sy sponsors the in an offort to avold misunders publishod.

At that time I wus avere that some of eriticlams were recarded, in Turkey, as unduly sovere. Thils was particulerly true in
respect of cortain tondencles uhich I bolloved I saw, tourd 2 rather oxtrove swing of the pendulin in the direction of stato controlled enterpr1sa, with a corresponting disregard - 25 I saw it - of tho potentialities of your sountryaen as lndilduals, onablod to develop and to mobilizo their oun captry afforced.
ducers in the various oconosile fields your country

Esch year since then I have made ohort risits to your country, and 1t has bean no socret among my friends there that 1 vas ploased turning point in your recent history.

Th1s swomor the Ed1tor of READER'S DIGEST suggested that I write a sorios of articles dealing with Middle East subjects, for something like 75 million Amerlean readers. One of these articles, I told the Editor, must surely be about Turkey, thus giving mo the double opportunity of aerving our own public lnterest, and at the same time paying the Turkish people the tribute which, soleiy besoomod to bo lacking in 1 t.

In saying this I do not nece to rotract (except whore I may In sayine this I do not nese to rotract (except hore I maen have beon in orror to oonvince mo that the kind of governaentel procrax that I sonsed then was needed in your country has since beor launched and I therofore regard it almost as an obligation upos mo to toll our Anericen peoplo that Turkey furnishes us with one of

\begin{tabular}{|l|l|l|l|l|l|}
\hline 030 & 01 & & 40 & 238 & 19 \\
\hline
\end{tabular}


Yaşar SEMİ, Güngör TOPLU-Cumhuriyet Döneminde Amerikan Emperyalizminin Türkiye'ye Girişi: Thornburg Raporu

$$
-2-
$$

the great examples of our timos of a country uhteh has ovolved primer1ly through 1ts own offorts and out of 1 ts own resources,
into a true democracy.

Particularly I vant our people to know that this has not cause of the Turki becauge of our aid progren, but prinerilly bec eccelerated by our aid. It is assential that our were merely understand this distinetion. It 1s also important that other people understand 1t, and realize that the first requiroment of any advancing nation $1 \mathrm{~s}$ a responsible governsent dedicated to the velfare of its poople. American aid may accolerate such an effort but 1 s not a substituto for 1 .

What $I$ would like to between now and the end of January is to roturn to Turkey for a fou weeks and make sure that I have the material necesary for the kind of articlo that I bave in-

I have presumed to address you in the hope that you right Indieate someone in your Government who would assist mo in making
this articlo as useful as possible in our rutual nationel interosts。

Very respectrully yours,

$$
\text { Thax Writare thamkery }
$$


5- Thornburg Raporunu hükümete verdi

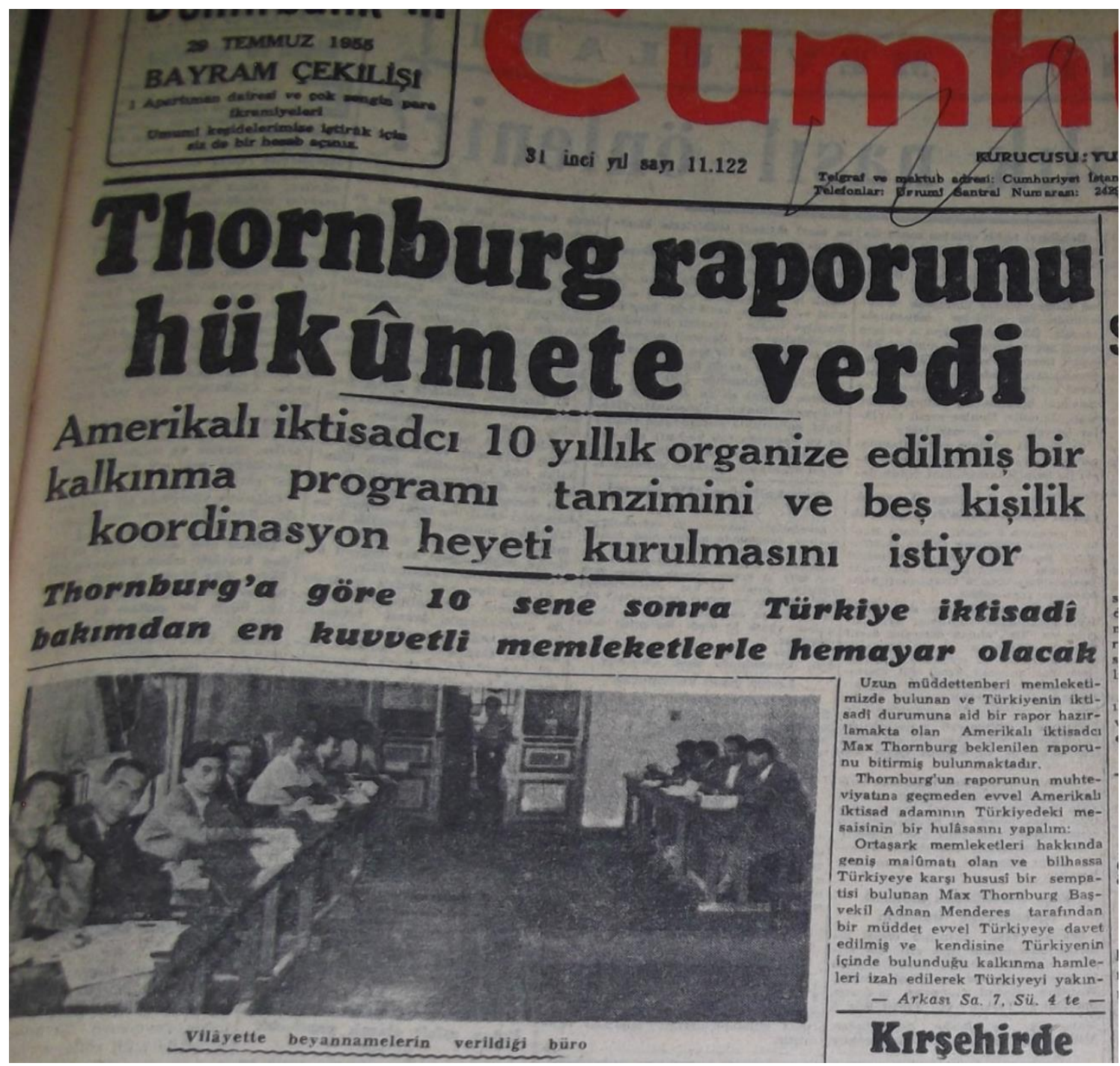


6-Reddedilen Amerikan Teklifi

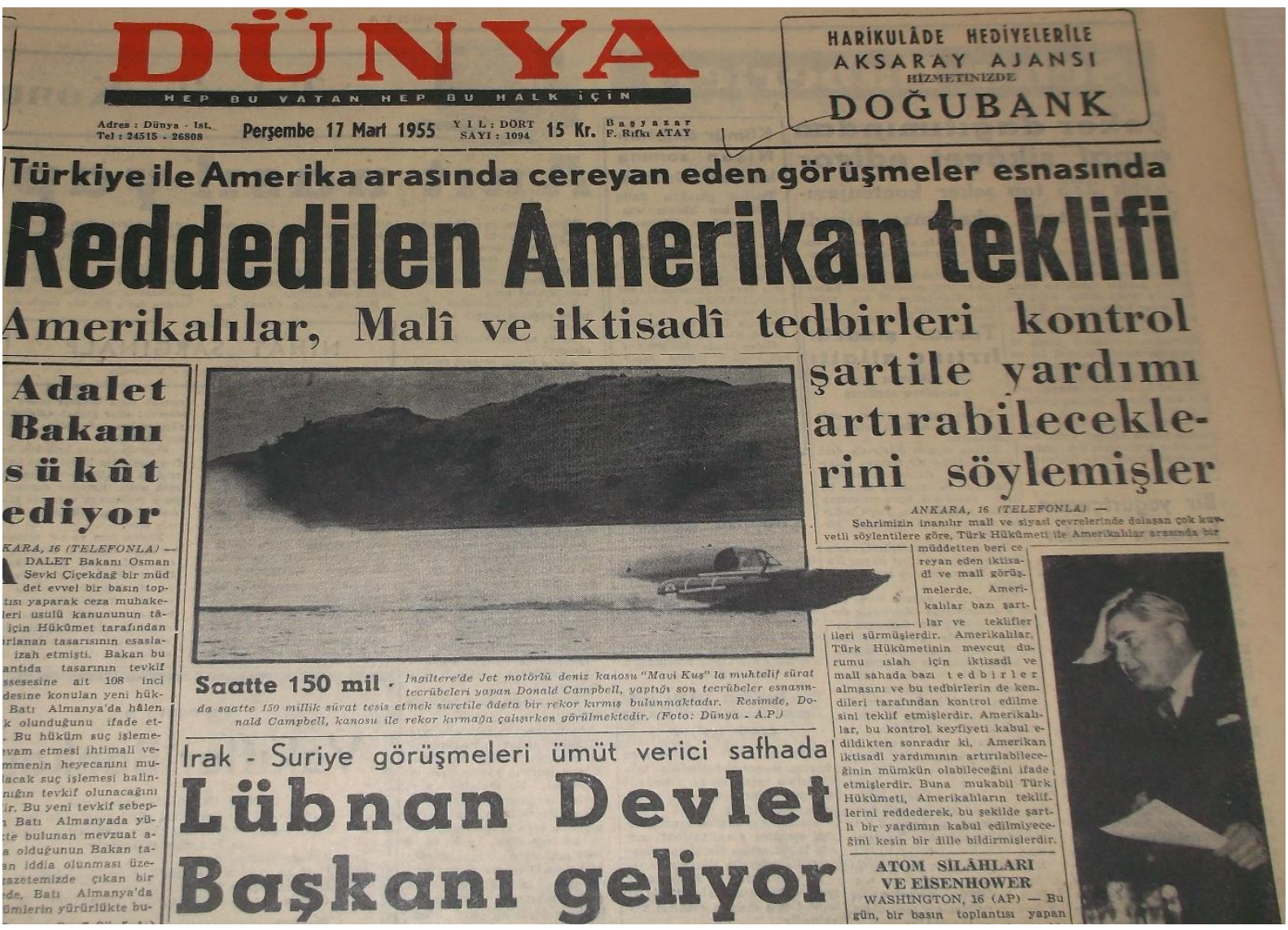

7- Rusya'nın Türkiye'ye Teklifi

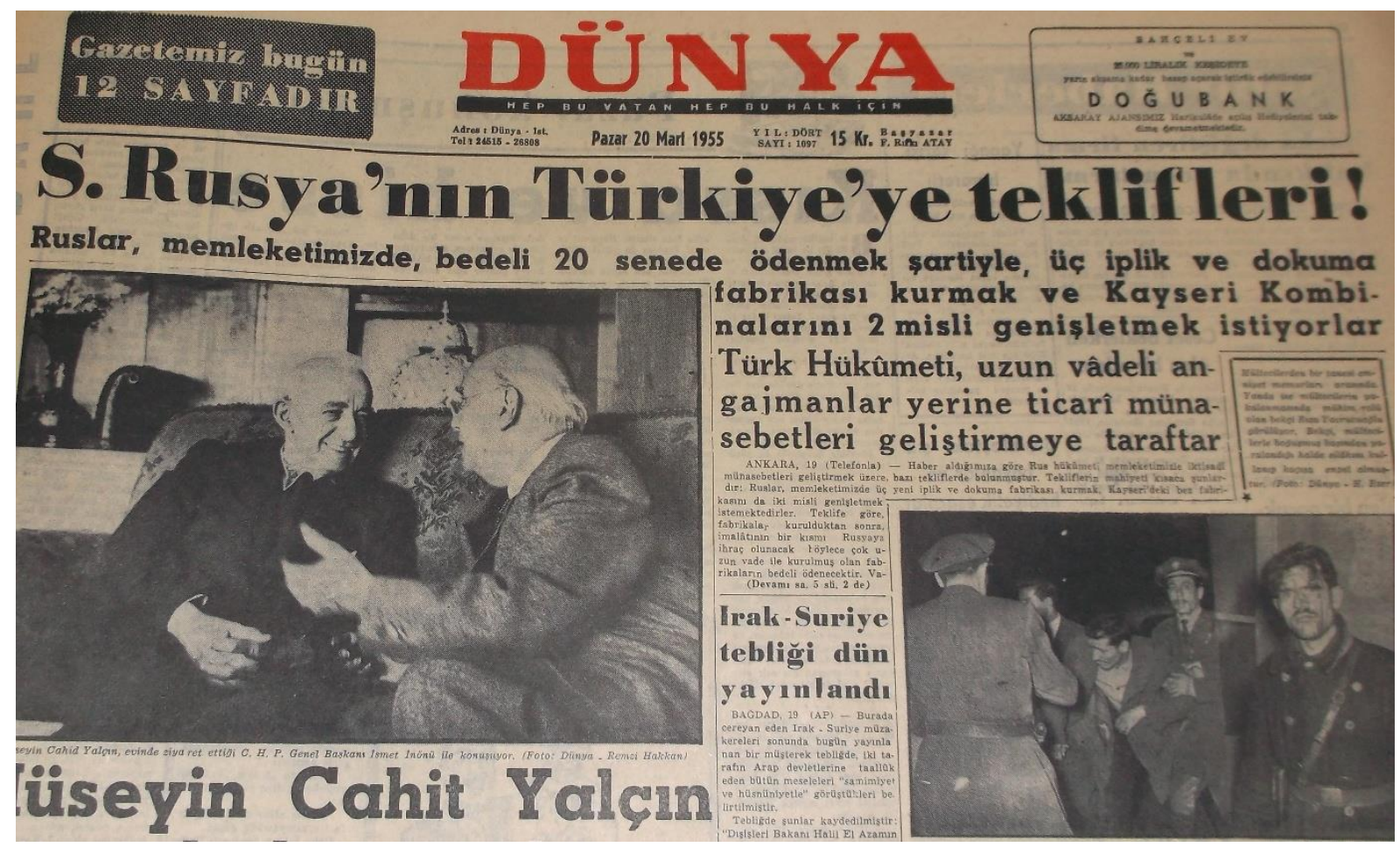

